\title{
ANIKAIVELIKI DRUG|
}

Sažetak: Veliki Drugi prema Lacanu (1966) svijet je jezika u kojem pojedinac konstituira sebstvo. Nerijetko to je prostor praznih označitelja u kojem je ljudski subjekt, lišen ikakve čvrste referentne točke, radikalno decentriran beskonačnim omaškama simboličkog poretka, uhvaćen $u$ narcističkim zrcalnim odrazima, raspršen i potpuno nadvladan neutaživom silom same žudnje. Lacan vjeruje da je navedena žudnja utaživa tek u aktivnom susretu s velikim Drugim, u uspješnoj interpersonalnoj komunikaciji koja je pak moguća tek u rijetkim trenutačnim bljeskovima.Tako poimana komunikacijska situacija stoga je doživljavana kao mjesto na kojem žudnja može biti utažena, ali i kao proces dijeljenja, nužna izlika koja prekriva trajnu potragu za nedostajućim objektom. Polazeći od navedenih Lacanovih teorijskih postavki prilog pokušava analizirati načine funkcioniranja ljubavnog diskursa i strategije konstituiranja intimnog sebstva u imperijalističkim društvenim porecima. Interpretacijom punog i praznog govora u Andrićevoj noveli Anikina vremena (1931) nastoji se pokazati načini realizacije sebstva rascijepljenog između žudnje i nedostatnosti osmanskog velikog Drugog.

Ključne riječi: Andrić, Anikina vremena, Lacan, veliki Drugi, Foucault, ars erotica

\section{Mali Drugi i(li) veliki Drugi}

„Drugost“" je vjerojatno jedan od najdiskutabilnijih i najkompleksnijih pojmova Lacanova cjelokupnog teorijskog aparata. Shodno tomu, iznimno je teško spojiti široku raznolikost područja i aspekata koje on navodi govoreći o „drugosti“. Analizirajući Lacanov subjekt Bruce Fink u studiji The Lacanian Subjekt, Between Language and Jouissance (1995) stoga s pravom navodi da Lacanov pojam „drugosti“ ima mnogo lica ili avatara. Lacanovo gotovo do ekstremnosti široko poimanje „drugosti“ „prelazi nevjerojatan raspon od nesvjesnog (Drugog kao jezika) i Ja (imaginarnog drugog [idealnog Ja] i Drugog kao žudnje [Ja-ideal]) do frojdovskog Nad-Ja (Drugog kao jouissance)“. ${ }^{1}$

1 Fink, B. (2009) Lakanovski subjekt. Između jezika i jouissance, Zagreb, str. XI. 


\section{BERNARDA KATUŠIĆ}

Vjerojatno najsloženiji odnos između navedenih „drugosti“ jest odnos između ,velikog“ (objekt „A“) i ,"malog“ Drugog (objekt, ,a“).

Posebice u eseju The Ego in Freud's Theory and in the Technique of Psychoanalysis (1955), Lacan pokušava lučiti razliku između „malog drugog“ i ,velikog Drugog“, paradoksno umjesto razjašnjavajući znatno još usložnjavajući navedena dva pojma. Grubo govoreći, francuski teoretičar ističe da je suprotno „velikom Drugom“, koji je upisan u simbolički poredak, „mali drugi“ upisan u imaginarni poredak. „Mali drugi“ istodobno je i pandan i odraz slike (imago) i zapravo i nije drugi, nego tek odraz ili projekcija ega. Za razliku od njega, „veliki Drugi“ jest jezik i zakon te je konceptualiziran kao radikalan alteritet i razlika. Kao takva „drugost“ „velikog Drugog“ nadmašuje iluziju drugosti imaginarnog poretka jer nikad u potpunosti ne iščezava kroz proces identifikacije. Štoviše, ,,veliki Drugi“ upisan je u simbolički poredak ne samo jezikom i zakonom nego i utoliko što je satkan od pojedinačnih subjekata. Shodno tomu, „Veliki drugi“ jest oboje, i drugi subjekt u svojoj radikalnoj razlikovnosti, kao i simbolički poredak koji posreduje odnose među subjektima. ${ }^{2}$ Pokušavajući objasniti relaciju između jezika i „drugosti“, Fink, $\mathrm{u}$ već spomenutoj studiji, $\mathrm{u}$ tom kontekstu ističe razliku između dvaju tipova diskursa ili, jednostavnije rečeno, između dvaju različitih tipova govora: ,govor ega: svakodnevni govor o onome što o sebi svjesno mislimo i vjerujemo i neku drugu vrstu govora $^{\text {‘3 }}$ zaključujući:

Lacanovo je Drugo, na svojoj osnovnoj razini, povezano s tom drugom vrstom govora. Pokusno možemo pretpostaviti ne samo da postoje dvije razlicite vrste govora nego i da, grubo govoreći, dolaze s dva različita psihološka mjesta: ega (ili sebstva) $i$ Drugog. (4)

Iz navedenog se nameće zaključak da je značenje „Drugog kao drugog subjekta“ podređeno značenju „Drugog kao simboličnog poretka“. „Drugi mora prije svega biti poiman kao mjesto, položaj u kojem se konstituira govor.“" Shodno tomu, moguće je govoriti o Drugom kao subjektu tek u drugorazrednom smislu, u smislu da subjekt može tek govorom zaposjesti navedeni položaj i tako „utjeloviti“ Drugog za drugi subjekt.

2 Usporediti: Lacan, J. (1988) The Seminar, Book II. The Ego in Freud's Theory and in the Technique of Psychoanalysis, 1954-55, New York: Nortion; Cambridge, poglavlje 19.

3 Fink, B. (2009) Lakanovski subjekt. Između jezika i jouissance, Zagreb, str. 3.

4 Lacan, J. (1993) The Seminar, Book III. The Psychoses, 1955-56, London, str. 274. 


\section{BERNARDA KATUŠIĆ}

\section{Puni i prazni govor}

Na slojevitost značenja „drugosti“ u jeziku i govoru Lacan se prvi put osvrće u poznatom ,rimskom govoru“ iz 1953., „Funkcija i područje govora u psihoanalizi“. Naglašavajući (raz)govor kao krucijalnu metodu (iz)lječenja traume on se u navedenom tekstu izravno nastavlja na Freuda znantno usustavljujući njegova poimanja govora i jezika. Lacan radikalno odbacuje tada uvriježene psihijatrijske metode liječenja zalažući se i detaljno razrađujući metodu (raz)govora. „Sve jedno ili je poimana kao metoda liječenja, kao stručna naobrazba, ili analiza dubinskog, psihoanaliza raspolaže isključivo jednim medijem: govorom pa-

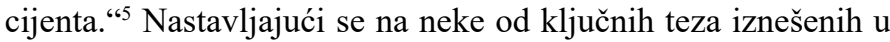
svojim prethodnim radovima - koje je krajnje pojednostavljeno moguće sažeti tvrdnjama: „nesvjesno je strukturirano kao jezik“, odnosno „nesvjesno je diskurs Drugog“, shodno čemu, ,ja jest Drugi“"6 - francuski teoretik u spomenutom eseju pobliže objašnjava ,jezik žudnje“ ističući da je traumu pohranjenu u nesvjesnom analizom određenih iskaza moguće, iako tek trenutačno i u svojevrsnim „bljeskovima“, dosegnuti i detektirati. Određujući, između ostalog, realno kao sve ono što tek trebamo simbolizirati, Lacan poima traumu kao jedno od lica realnog, točnije, kao nešto što stoji između jezika i realnog. Jezik nikada u potpunosti ne transformira realno, nikada ne odlijeva sve realno u simbolički poredak, ostavljajući uvijek za sobom neki reziduum. Trauma je za njega to reziduirano iskustvo, iskustvo koje je subjektu postalo kamen spoticanja, otpadak realnog, svojevrsna „regresija realnog“ (90). Kao takva, trauma po Lacanu implicira fiksaciju ili blokadu, nešto što još nije simbolizirano. Kako bi objasnio načine i mogućnosti simboliziranja ostataka realnog na kojima počiva trauma, mehanizme funkcioniranja i razumijevanja „jezika žudnje“, Lacan u spomenutom eseju razlikuje „prazni“ $\mathrm{i}$,puni“" govor (parole vide / parole pleine) ${ }^{7}$, odnosno istinit $\mathrm{i}$

5 Lacan, J. (1973) Schriften I, ur. N. Haas. Walter Verlag: Olten / Freiburg, str. 84 .

6 Kao što je nerijetko isticano u literaturi, Lacanova teorijska građevina iznimno je kompleksna i nepristupačna. Detaljno diferenciranje njegovih pojedinačnih teza, koje su se često mijenjale u različitim vremenskim kontekstima i teorijskoj argumentaciji, znatno bi prelazilo okvire ovoga rada. Teze zastupljene ovdje utemeljene su isključivo na autorovim radovima navedenim u sekundarnoj literaturi. U kontekstu netom iznešenih teza usp. između ostalog: Lacan, J. (1973) Schriften I, ur. N. Haas. Walter Verlag: Olten / Freiburg, str. 104 i 113; Lacan, J. (1975) Schriften II, ur. N. Haas. Walter Verlag: Olten / Freiburg, str. 190 i 178; Lacan, J. (1978) Die vier Grundbegriffe der Psychoanalyse, Das Seminar von J. Lacan, ur. J.-A. Miller, knjiga br. XI, Olten / Freiburg, str. 26.

7 Usporediti: Lacan, J. (1973) Schriften I, ur. N. Haas. Walter Verlag: Olten / Freiburg, str. 84, 92-93. U istom eseju na jednom drugom mjestu „puni govor“ Lacan naziva i ,prvim jezikom (langage premier)“(136). 


\section{BERNARDA KATUŠIĆ}

lažni govor, ističući da je zadaća psihijatra prodrijeti u spomenutu ,regresiju realnog“ (90), tj. u nesvjesnu razinu jastva (je), koju Lacan diferencira od svjesne (moi), i potaknuti pacijenta da (pro)govori iz nje i o njoj.

Praktična zadaća psihoanalize stoga bi po Lacanu bila staviti subjekt u svojevrsnu „scenu govora“, otkočiti, osloboditi, spoznati i priznati ga, iza maske praznog govora doći do punog govora (usp. 104). Takvu zadaću Lacan naziva svojevrsnom ,psihonalitičkom anamnezom“ koja ne teži rekonstruirati „realitet“, nego „,istinu“, djelovanjem „punog govora“, njegovim novim „poslagivanjem“ i „osmišljavanjem“ prošlosti (95). Tek u takvoj „scenskoj“" govornoj konfiguraciji moguće je doprijeti do istine, moguća je realizacija „punog govora“, „govora žudnje“, iskaza nesvjesnog.

Kao daljnju karakteristiku ,punog govora“ Lacan ističe činjenicu da je on odrediv i spoznatljiv tek u odnosu s ,,drugim“" subjektom. Istinit govor moguć je tek u dijalogu, susretu subjekata, nesvjesno je moguće iskusiti tek u dijalogu, tek u dodiru s drugim, nikako u imperativu samotne refleksivnosti. Za puni diskurs nužna je riječ koja istovremeno može biti i jedno i drugo, odnosno, kako tvrdi Lacan, samo riječ primljena obostranim priznanjem može utažiti žudnju (usp. 143). Značajka punog diksursa je i u tome da je govor jednoga istovremeno i govor drugoga, $u$ tome da riječ koju jedan upućuje drugom pogodi i naiđe na odjek i time prodre u nesvjesno otkrivajući i spoznajući, ali uvijek tek trenutačno i samo u „bljeskovim“, istinu, vlastito sebstvo. Tamo gdje izgovorena riječ iznjedri drugu riječ, jezik bljesne istinom, koja ne pripada ni jedno ni drugoj strani, nego bivstvuje između govornika.

To mjesto drugog, odašiljanje riječi i njezin prijem u drugom iznimno je kompleksno i slojevito. Kako bi ga pojedinac iskusio, kako bi se realizirao puni diskurs, onaj koji utažuje žudnju, Lacan naglašava niz mehanizama koji na prvi pogled djeluju krajnje paradoksalno. Navest ću samo neke koji će biti potka daljnje analize. On, između ostalog, navodi pogrešan iskaz, šutnju i ,jezične simptome" kao ključne načine funkcioniranja punog diskursa i dosezanja jezika žudnje. Nadovezujući se na Novi zavjet na jednom mjestu ističe da je za analitičara važno ,imati uši kako ne bi čuo ili, drugačije rečeno, kako bi razotkrio ono što treba biti čuto i razumljeno“ (92) jer analitičar ne posjeduje treće ili četvrto uho kojim bi mogao čuti ono što je u podsvijesti.

Evidentno je da tako poiman jezik sa sobom istovremeno donosi utaženje žudnje, ali je i temeljni oblik otuđenja. Jezik koji stalno balansira na granici između istine i laži, ,punog i praznog govora", kao takav dopušta perfidnost, izvještačenost, laži, prijevare. 


\section{BERNARDA KATUŠIĆ}

Stoga on istodobno traumatizira i liječi, potiče i utažava žudnju. $\mathrm{U}$ tom kontekstu jezik i interpersonalna komunikacija primarno se nadaju kao nužne izlike, fasade koje otkrivaju/prekrivaju nemogućnost utaženja žudnje, a sama se komunikacijska situacija doživljava kao proces dijeljenja, u kojem ljudski subjekt stalno ponavlja svoju trajnu potragu za nedostajućim objektom ili žudnjom.

Polazeći od navedenih Lacanovih teorijskih postavki u daljnjem se dijelu teksta pokušava analizirati načine funkcioniranja ljubavnog diskursa i strategije konstituiranja intimnog sebstva $u$ imperijalističkim društvenim porecima. Interpretacijom „punog“ i ,praznog“, govora kako ih poima Lacan ${ }^{8}$, u Andrićevoj noveli Anikina vremena (1931) nastoji se iščitati načine iskazivanja koji sugeriraju traumatizirana stanja likova te pokazati modalitete realizacije sebstva rascijepljenog između žudnje i nedostatnosti osmanskog ,velikog Drugog“.

\section{Ljubeći Drugi}

Strah, ludilo, bol, bezizlaznost, egistencijalna tamnica, estetika „svijeta bez boga“", toposi su koji su već navođeni u literaturi $\mathrm{u}$ analizi kako cjelokupna Andrićeva opusa, tako i pripovijesti Anikina vremena.$^{10}$ Već je na prvi pogled evidentno da u dijagetičkom univerzumu gotovo i nema lika koji nije iskusio ili ne trpi kakvo traumatsko stanje. Atmosfera boli, ludila i bezizlaznosti nerijetko je eksplicitno i izrečena u naraciji. Tako je, primjerice, $\mathrm{u}$ tekstu predstavljeno kako pop Vujadin gleda sama sebe kako iz dana u dan „ludi i gubi se“ (15) te konačno jednog dana prelazi na „otvoreno ludilo“ (16), Mihailo je karakteriziran kao netko tko zbog proživljene i neverbalizirane trauma s Krstinicom nalikuje „teškim bolesnicima” (44), a Lale zbog šutnje u koju se zaodjenuo nakon skandaloznog sestrina ponašanja prikazuje se kao „malouman“ (29), „luckast“ (30) i “srećni idiot” (82). Iako naratološka postavka uzroke traumatskih stanja likova ne ograničava na samo jednu pojavu nego ih naprotiv sugerira nerazmrsivom kompleksnošću najrazličitijih uzroka i posljedica, neostvarenu ljubav prema osobi suprotnog spola, neutaženu žudnja za ljubećim Drugim, moguće je čitati kao jednu

8 Usporediti: Lacan, J. (1973) Schriften I, ur. N. Haas. Walter Verlag: Olten / Freiburg.

9 Takvu egzistencijalističku potku Andrićeva poetskog kozmosa najuvjerljivije i najdetaljnije razradio je Korać u studiji Andrićevi romani ili svijet bez boga, 1970. Iako se Korać u svojoj studiji eksplicite ne referira na pripovijest Anikina vremena, navedene poetske karakteristike karakteriziraju i to prozno štivo.

10 Usporediti: Minde, R. (1962) Ivo Andrić, Studien über seine Erzählkunst, München, str. 190; Korać, S. (1989) Andrićevi romani ili svijet bez boga, Zagreb. 


\section{BERNARDA KATUŠIĆ}

od ključnih tematskih okosnica Andrićeva teksta. ${ }^{11}$ Motrena s aspekta nerealizirane ljubavi pripovijest Anikina vremena satkana je od četiri autohtone ljubavne priče: priče o pop Vujadi$n u$, posljednjem izdanku obitelji Pobrunović koji nakon ženine smrti poludi, priče o Aniki, višegradskoj kurtizani koja, iako fatalnom ženskošću cijelu kasabu "baca na noge”, postaje tako moćna da neko vrijeme vlada ljubavnom žudnjom gotovo svakog člana kasabe, tragično okončava ostajući sama zakinuta za žuđeni objekt ljubećeg Drugog, priče o Mihailu, koji traumatiziran ljubavnom aferom s Krstinicom ostaje nesposoban za ljubav, te priče o pop Vujadinovu djedu Jakši koji zbog nekontrolirane ljubavne žudnje za Anikom izvrgava ruglu sebe i vlastitu obitelj.

Navedena traumatska stanja inducirana neutaživom žudnjom ljubećeg Drugog u tekstu su sugerirana diskurzivnom slojevitošću koja karakterizira sve pripovijedne segmente: fabularnu

$11 \mathrm{U}$ dosadašnjoj literaturi Andrićeva pripovijest uglavnom je čitana kao jedna od „ženskih priča“. Suprotno „,starijoj“ kritici koja je polazila od egzistencijalno-ontološkog pojmovlja ljepote, dobra i zla, i u Anikinu liku vidjela ili „slik[u] mutnih i nerazumljivih strana ljudskog života“ (Korać, S. (1989) Andrićevi romani ili svijet bez boga, Zagreb, str. 551) ili „pad“ i ,greh“ koje treba kazniti (Stojanović, D. (2016) Lepota i mržnja, http://www.rastko.org.rs/ knjizevnost/nauka_knjiz/andric/dstojanovic-anika.html, 20. 05. 2016.), ,novija“ čitanja uglavnom zasnovana na (post)feminističkoj vizuri ili recentnim promišljanjima sebstva, ne vjeruju više da u Anikinom misterioznom liku stoluje ,zlo“ po sebi, nego tvrde da ono nije „u samoj ženi, već u sankcioniranoj, društveno proskribiranoj muškoj želji“ (Lukić Visković, J. Dvije Andrićeve ženske priče: „Anikina vremena“ i „Mara milosnica“, u: Ivo Andrić - svugdašnji, ur. Brnčić, J. (2015), Zagreb, str. 110). U tom smislu recentna čitanja Anikinih vremena u tekstu detektiraju ili ,modele muškocentričnog pisma“ (Đuvić, M. (2016) Žena koje nema i njeno tijelo. (Re)konstrukcija ženskog subjekta u Andrića, http://www.razlika-differance.com/Razlika\%205/RD5Djuvic.pdf, 20. 05. 2016, str. 2) ili ,tjelesnost koja se otela patrijarhalnoj kontroli“ (Gazetić, E. (2016) Ne/predstavljivost ženskog subjekta u Andrićevim pripovijestima. „Anikina vremena “, „,Mara milosnica“ $i$ „Jelena, žena koje nema “, https://www.ceeol.com/search/article-detail?id=33077, 20. 05. 2016., str. 95), ili pak u Anikinu liku vide ilustrativni primjer „razlomljenog i rascijepljenog subjekta" (B Brlenić-Vujić, B. Razlomljeni identiteti u Andrićevim pripovjetkama, u: Ivo Andrić - književnik i diplomata u sjeni dvaju svjetskih ratova (1925-1941), ur. Tošović, B. (2012), Beograd, str. 119). Iako neka od navedenih tumačenja Andrićeve pripovijesti u svojim analizama referiraju i na ovdje korišteno pojmovlje Drugost i govorne komunikacije (usp. Brlenić-Vujić (2012), nav. djelo, str. 120-123 i Đuvić (2016), str. 4), niti jedno se izravno ne referira na Lacanovu teoriju, ali niti ne pozicionira i diferencira navedenu problematiku u kontekstu suvremenih, iznimno slojevitih i složenih promišljanja. U okvirima ovdje korištenih teorijskih okvira potrebno je istaknuti i interpretaciju Tatjane Bečanović koja pripovjedne strategije Anikinih vremena raščlanjuje polazeći od Genetteove naratološke teorije, ali suprotno ovdje primjenjivanim pojmovima elipse, paralipse, distance i glasa, svoju interpretaciju usredotočava na Genettovu kategoriju narativnog nivoa (usp. Bečanović, T. Kompozicioni principi Andrićevih pripovjedaka „Anikina vremena“ i „Mara, Milosnica“, u: Ivo Andrić - književnik i diplomata u sjeni dvaju svjetskih ratova (1925-1941), ur. Tošović, B. (2012), Beograd, str. 212). 


\section{BERNARDA KATUŠIĆ}

okosnicu, poziciju pripovjedača, karakterizaciju lika, iskaz lika itd. Navedena diskurzivna slojevitost posebice je vidljiva u načinu izvedbe izravne komunikacije među likovima u njihovim (neuspjelim) nastojanjima dosezanja ,punog“ ili ,,istinitog“ govora. Komunikacija između Anike i Mihaila u tom smislu izdvaja se kao kulminacijska točka ne samo njihova (ljubavnog) odnosa nego i cjelokupne sižejne konstrukcije i semantičke intencije.

\section{Anikini i Mihailovi (raz)govor(i)}

U tekstu nije iznesen precizan podatak koliko su se puta Mihailo i Anika susreli i razgovarali. Način njihove (ne)komunikacije kada, koliko, kako i što su razgovarali - moguće je tek (neizravno) iščitati iz pripovjedačevih navoda i komentara. Na točno devet mjesta $u$ tekstu izvještava se o susretima Anike i Mihaila i njihovoj (ne)komunikaciji. U prvom navodu pripovjedača čitatelj saznaje da su se sreli slučajno, netom nakon što je Anika „pala [...] svima u oči“ (27) i „zadevojčila“ se (28), u javnom prostoru, točnije, ,pri ulasku i izlasku iz crkve“" (27). Jesu li razgovarali, i ako, što nije jasno rečeno.

A Anika je prošla kroz svetinu polako, novim korakom i u novom liku, ne gledajući ni preda se i ni u koga od onih što su u nju gledali, nego pravo u vrata na porti prema kojima je išla. Na vratima se susrete, sudari gotovo, sa jednim muškarcem. To je bio Mihailo Nikolin zvani Stranac. Malko se zbuniše i zaustavi$\check{s}$ e, više on nego ona, i pređoše prag, jedno mimo drugog, gotovo u isti mah. (28)

Drugi put susreću se na istom mjestu, ,ali više ne slučajno“. Je li došlo do razgovora, i ako je, o čemu su pričali ni ovaj put u tekstu nije jednoznačno određeno. Znakovito je da je u relativno kratkoj sekvenci koja opisuje njihov susret posvećeno znatno više prostora reakcijama i ,govoru“ kasabe, nego njima samima i njihovim (raz)govorima. Iduće nedelje po Bogojavljanju sastali su se na istoj kapiji, ali ne više slučajno. Mihailo je očekivao i prišao joj. A svet koji je bio iznenađen naglim i neobičnim preobražajem Anikinim, čudio se isto toliko da Mihailo, koji nije išao ni sa svojim vršnjakinjama, sačekuje i prati nju. Kasaba nije prestajala da govori o Krnjojelčevoj kćeri koja se odjednom zadevojčila, i to tako da odudara i likom i odelom od ostalog ženskog sveta. (28) Pri trećem navodu pripovjedač ponovno izvještava da su se Mihailo i Anika viđali redovito na istom mjestu, ovaj put ističući i to da su, iako kratko, međusobno komunicirali: „Mihailo je isprva redovno sačekivao u porti i izmenjivao sa njom po nekoliko reči.“ (29) O čemu su razgovarali te kako su susreti bili dogovarani, ni ovaj put nije naznačeno. Suprotno tomu, i sada je čitatelj znatno podrobnije obaviješten kako su njihovi sastanci i razgovori bili percipirani u kasabi: Anika je 


\section{BERNARDA KATUŠIĆ}

te zime bila „glavni predmet muških želja i ženskih razgovora“ (29). Pri četvrtom navodu pripovjedač vrlo koncizno izvještava čitatelja da su Anika i Mihailo, zajedno s drugim „momci[ma] kod crkve" razgovarali o udaji. I u ovoj narativnoj sekvenci reakcijama kolektiva dodijeljen je izniman značaj. Kasaba je govorila o Anikinoj udaji. O tom su joj govorili svakako i momci kod crkve. Ona ih je gledala sve podjednako i slušala mirno, najčešće i ponajduže Mihaila, ali sama nije odgovarala nikad ništa određeno. (30) Pri petom navodu saznajemo da je Mihailo prestao Aniku ,sačekivati“. I ovaj put pripovjedač vidljivo fokusira i fokalizira reakcije naroda na novonastalu situaciju, dok su Anikina i Mihailova razmišljanja i doživljaji u drugom planu. Ženili su ga mnogi, ali on je odbijao uvek šalom ili ćutanjem. Zato je bilo veliko iznenađenje kada je pretprošle zime počeo da se viđa i razgovara sa Anikom, ali još mnogo veće kada je ovog proleća najednom prestao da je sačekuje. Svet se pitao što je moglo biti između neobične Krnojelčeve kćeri i ovog Mihaila, o kome se i inače ne zna ništa, i gubi se samo u nagađanjima. (32) Pri šestom navodu narator još jednom sažima, sada iz Mihailove perspektive, njihove dotadašnje susrete i razgovore. Navodeći i razlog koji je najvjerojatnije spriječio ostvarenje Anikine i Mihailaove ljubavi - Mihailo je „strepeo od Krstinice u sebi“ (41) zaključuje: „Tako im je prošla godina dana bez pravog sporazuma i bez konačnog prekida.“ (41). Tek iz sedmog navoda čitatelj saznaje sadržaj Anikina i Mihailova razgovora. Navedena komunikacijska situacija izdvaja se u odnosu na sve dotadašnje i po tom što je unaprijed dogovorena, realizirana preko fizičkog posrednika, stare Pleme, te po tome što je prva koja se odvija u privatnom prostoru (Anikinu domu).

Zvala ga je da ga pita što misli da radi na Đurđevdan. Između njenog muklog, teškog glasa, belog lica bez osmejka i ove sitnice koju ga je pitala, bio je velik nesrazmer koji je još više zbunjivao Mihaila. Pošto su se sporazumeli i pošto je on obećao da će svakako ići na đurđevdanski teferič ,, ako bude živ“, Anika doda:

- Ija ću, ako budem živa i ako se ne udam.

- Nećeš valjda za ovo nekoliko dana.

- Svašta ja mogu učiniti.

- Nećeš, nećě̌.

- Mislǐs?

Ta poslednja reč, neobično izgovorena, prisili ga da joj pogleda u lice. (41-42)

Osmi put pripovjedač izvještava o susretima i razgovorima koji su također bili planirani, ali neostvareni. Svi oni trebali su se 


\section{BERNARDA KATUŠIĆ}

odvijati u Anikinu domu, sve ih je, kao i prethodni, inicirala Anika te su svi bili posredovani preko Pleme. Kad ga je Plema još jednom zvala Aniki, odgovorio je da ne može doći. Kad je, uoči Đurđevdana, ponovno došla da ga pita za teferič, odgovorio je da neće ići. Još mu je jednom Anika poručila, sutradan po Đurđevdanu, „da kaže hoće li doći ili neće“. „Ne mogu“, odgovorio je, i ostao u očekivanju događaja kao što se očekuje udarac. (44) I deveti pripovjedačev navod izvještava o namjeravanom, ali također neostvarenom susretu i razgovoru, koji ovaj put inicira Mihailo, također preko posrednika, Anikine ciganke. Kada Mihailo dolazi u Anikin dom u zakazano vrijeme, do razgovora ne dolazi jer on u njezinoj sobi nalazi Anikino mrtvo tijelo (usp. 86-87).

\section{Naoko beznačajna sitnica}

Kao što je istaknuto, sedmi navod pripovjedača izdvaja se u odnosu na sve ostale jer njime počinju unaprijed dogovarani razgovori, on je prvi koji se odvija u privatnom prostoru, jedini u kojem dolazi do izravne komunikacije između Anike i Mihaila te jedini u kojem narator čitatelju prenosi sadržaj njihova razgovora u cjelosti. Usprkos tomu, na prvi je pogled, sadržaj njihova razgovora suvišan, potpuno praktične naravi, naoko beznačajna „sitnica”, kako je eksplicite vidi Mihailo, Anikino pitanje Mihailu što namjerava raditi na Đurđevdan. Susret se nadaje nepotrebnim i stoga što su dogovor o „đurđevdanskom teferiču” mogli utanačiti i preko posrednika. Iznimna kratkoća njihova razgovora, kao i odrješitost i lapidarnost izraza te posebice učestale, naoko potpuno redundantne jezične poštapalice - primjerice, ,nećeš valjda“, „misliš“, ,ako budem živ“, ,ako budem živa“, koje bi na prvi pogled mogle upućivati na upotrebu tipičnih jezičnih frazema koji boje bosansko podneblje, te njihove inačice ,ako se ne udam" - sugeriraju sporednost i trivijalnost njihove komunikacije. U tom kontekstu promatran razgovor između Anike i Mihaila moguće je čitati kao šalu ili praznu igru riječima. Međutim, iscrpnijom analizom, ponajprije usporedbom navedene govorne situacije s drugim u dijagetičkom univerzumu prestavljenim govornim aktovima, te posebice stavljanjem navedene govorne scene $u$ kontekst cjelokupna narativnog ustoroja, na vidjelo izlaze znatno dublje značenjske razine.

Još je Freud istaknuo da nema izrjeka bez značenja. Dapače, šale, jezične marginalije, najrazličitiji lapsusi, jezične omaške, nenamjerno izgovorene, izlanute, promumljane ili pobrkane riječi po njemu su najbolji put prodiranja u nesvjesno, svojevrsna 


\section{BERNARDA KATUŠIĆ}

„via regia“ nesvjesnog. ${ }^{12}$ Izravno se nadovezujući na Freuda Lacan navedene jezične marginalije naziva svojevrsnim jezičnim „simptomima“ ističući da je svaka „omaška,“ svaki „lapsus“ organiziran kao usustavljen jezični diskurs. Iskrivljeni govor i pomiješane riječi približavaju nas ,građi“ jezika više nego pravilno artikulirane rečenice. Kao takve jezične marginalije nadaju se kao mostovi između simboličkog i realnog iskazujući i konstituirajući subjekt znatno dublje nego druge riječi. ${ }^{13}$

Već analiza navedene govorne situacije s aspekta sižejne postave, detektiranje trenutka u kojem se odigrava, znatno nadilaze na prvi pogled sugeriranu semantiku nehajne šale ili igre riječima, bacajući na nju potpuno novo značenje. Najavljujući navedenu narativnu sekvencu pripovjedač je naziva „prelomom“ (41), priopćavajući nam netom nakon njezina iznošenja kako se Anika, budući da do planiranog susreta ipak ne dolazi, nakon „đurđevdanskog teferiča“ znatno mijenja kako prema Mihailu, tako i prema sebi samoj i cijeloj kasabi. Događaje koji su slijedili nakon navedenog komunikacijskog akta pripovjedač ovako opisuje:

Otada pa do ilindanskog vašara, ona je potpuno razvila barjak. Otvorila je kuću muškarcima; nabavila neke dve seoske skitnice, Jelenku i Savetu, da joj budu kao dvorkinje. Od tog vremena pa za godinu i po dana, ona je smišljala zlo i nesreću kao što drugi svet misli o kući, deci i hlebu, žarila je i palila ne samo po kasabi nego po celom kadiluku višegradskom, $i$ izvan njega. Mnogo se od toga poboravilo, a mnoga je muka ostala zauvek neviđena i nekazana, ali tada se tek uvidelo šta može da počini žena otpadnica. (44-45)

Promotrimo li usto navedenu govornu situaciju s aspekta dominantne narativne strategije, rastvaraju se daljni semantički slojevi. Tko što zna i u kojem obujmu u određenom trenutku, moguće je istaknuti kao ključni narativni rekvizit koji povezuje naoko disparatne narativne cjeline i pokreće radnju. Rečeno Genetteovom terminologijom, elipsa i paralipsa, ${ }^{14}$ dominantni su narativni postupci kojima Andrić konstruira fabularnu okosnicu. Međutim, Andrić ih rabi na osebujan način. Za razliku od elipse koja je, kako navodi Genette, primarno vremenske naravi i operira izostavljanjem, odnosno ,preskakanjem“ određenih radnji na koje se više ne vraća i osvrće, ili paralipse koja važne, ključne

12 Usporediti: Freud, S. (1940) Zur Psychopathologie des Alltagslebens, u: Sabrana djela IV, ur. Freud, A., Bibring, E., Hoffer, W., Kris, E. i Isakower, O. London / Frankfurt a. M., str. 256 i 268.

13 Usporediti: Lacan, J. (1973) Schriften I, ur. Haas, N. Walter Verlag: Olten / Freiburg, str. 108-109.

14 Usporediti: Genette, G. (2010) Die Erzählung, Stuttgart, str. 66 i 29-30. 


\section{BERNARDA KATUŠIĆ}

događaje vremenskog prostora o kojem se izvještava u jednom trenutku ostavlja „po strani““ (30) i povjerava ih čitatelju u nekom drugom vremenskom segmentu, ,retroaktivno ih fokalizirajući“ (30) dajući im tako dodatne semantičke razine, u Andrićevu tekstu izostavljeni događaji, ključne niti narativnog zapleta ostaju zamagljeni i do kraja neizrečeni. Štoviše, izostavljene akcije i motivi Andrićeva dijagetskog univerzuma umjesto retrogradno rasvijetljeni, gotovo redovito su, najrazličitijim narativnim strategijama, još znanto zatamnjeni. U tom smislu tehniku narativne šutnje, odnosno princip tajne, moguće je istaknuti kao ključnu tehniku pripovjednog oblikovanja Andrićeva fiktivnog svijeta. Tako, primjerice, narativni ishodi gotovo svih sižejnih linija ostaju do kraja nerazjašnjeni. Kakav je uistinu bio pop Vujadinov „unutarnji život“ nakon smrti njegove supruge, ostaje tajanstveno. Ta pop Vujadinova „tajna stvarnost“ (20), koja u sižejnoj strukturi funkcionira kao jedan od ključnih pokretačkih motiva, ostala je kako za njega sama, tako i za kasabu, pripovjedača i čitatelja dokraja sakrivena. Završavajući narativnu sekvencu o njemu pripovjedač nedvosmisleno zaključuje: ,,popVujadinova sudbina je stajala pred njima [kasablijama] prosta a neobjašnjiva“" (24). Informacijama o sižejnoj liniji koja prati razloge i način Krstina umorstva raspolažu samo sudionici zločina, Krstinica, Mihailo te čitatelj. Činjenica da samo oni imaju uvid u navedenu scenu, odnosno način kako se oni verbalno odnose prema proživljenim iskustvima, funkcionira kao jedna od snažnih semantičkih razina. Primjerice, Mihailovo neuravnoteženo psihičko stanje, uzrokovano ponajprije navedenim događajima, sugerirano je time što se on o njima ne usudi i ne želi svjedočiti (,ni u najtežoj vatri nije se odao“, 38), nazivajući sam situaciju koja ga je snašla „tajnom“ (38), odnosno „tajnom mukom“ (40). Krstinica, s druge strane, očito također traumatizirana navedenim zbivanjima, ne libi se verbalno ih predstaviti, štoviše, ne prestaje do u najsitnije tančine o njima govoriti. Da su oni i njoj nesavladiv psihički teret, proizlazi ne samo iz njezine vidljivo burne verbalne reakcije nego i stoga što ih ona predstavlja u odnosu na Mihaila na potpuno ,iskrivljen“ način. Njezina konfabulirana priča o hajducima koji su, navodno, noću, naoružani, neočekivano banuli u njihov dom i usmrtili Krstu čitatelju već poznate narativne podatke ne predstavlja samo iz bitno drugačijeg rakursa nego ih istovremeno i proširujuje, ali i zamagljuje. Način kako Mihailo i čitatelj saznaju Krstiničinu „verziju“ - preko sluškinje Jevre koja je „stala da kazuje šta je čula u komšiluku“ (37) - navedene događaje zaodijeva još jačim tajnovitim velom. Događaji za čitatelja zadobivaju na tajanstvenosti i time što je on u njih upućen prije čaršije, koja inače „sve zna“, te činjenicom da Krstinica i Mihailo nikada ne pričaju o njima (barem na osnovi onoga što pripovjedač eksplicitno podastire u 


\section{BERNARDA KATUŠIĆ}

tekstu). I konačno, središnja „tajna“, zašto Anikina i Mihailova ljubavna žudnja ostaju nutažene te tko i zašto usmrćuje Aniku, kako za kasablije tako i za čitatelja, ostaju dokraja nerazmršeni.

U takvom narativnom poretku navedena govorna situacija između Anike i Mihaila višestruko je znakovita. Naime, narativni signali, činjenica da Anika i Mihailo pripremaju sastanak, da razgovaraju izravno i u zatvorenom privatnom prostoru te sadržaj naoko nehajne poštapalice ,ako budem živa i ako se ne udam“, upućuju na to da bi se sada mogla razriješiti središnja sižejna tajna: za koga će se Anika udati i kako će završiti njezina sudbina? Međutim, kako se razabire iz daljnjeg fabularnog tijeka, njihov razgovor ne razotkriva tajnu, nego je dodatno komplicira i usložnjava.

\section{Govorna distanca}

Promotrimo li Andrićev narativni iskaz s aspekta „distance“ $\mathrm{u}$ Genetteovu smislu ${ }^{15}$, vidljivo je da u njemu prevladava ,pripovjedni govor“ (109). Kako u cjelokupnu njegovu proznom stvaralaštvu, tako i u Anikinim vremenima, izravan govor likova (110) iznimno je rijetko korišten. Ne samo zbog navedene sporadičnosti nego i zbog skale najrazličitijih, često značenjski suprostavljenih sadržaja koje prenosi takav tip govora, on odiše posebnom semantičnom nabijenošću. Ilustrativno navodim samo neke od sadržaja koji su u tekstu prestavljeni u formi upravnog govora. Nerijetko su to najnabijenija značenjska mjesta kao, primjerice, u pop-Vujadinovoj pripovijesti rješenje njegove nedoumice koja ga muči tijekom cjelokupnog narativnog tijeka - je li njegovo pshičko stanje u kojem se zatekao normalno ili nije. Odgovor je dan u jednoj jedinoj riječi koju pripovjedač prenosi u obliku upravnog govora: „Ludim!“16. Mihailova dvojba što učiniti s nožem neposredno prije posljednjeg susreta s Anikom kulminira iskazom: „Došlo je vreme da se izvadi nož iz rane.“ (79). Takav iznimno snažan značenjski moment prestavljaju svakako i Anikine riječi prenesene u upravnom govoru: „Osevapio bi se ko bi me ubio.“ (75). Ne samo da su to jedine riječi kojima Anika opisuje svoje psihičko stanje nego one neizravno sugeriraju odgovor na ključnu narativnu dilemu, što želi i kako se osjeća Anika, zašto njezina ljubavna žudnja ostaje neutažena, te nagovješćuju konačni sižejni ishod (njezino umorstvo). S druge strane, nerijetko su u značenjski iznimno nabijenim pripovjednim segmentima u obliku izravnog upravnog govora prenesene naoko banalne trivijalnosti, primjerice, u sceni borbe Krstinice s njezinim mužem njezino obraćanje Mihailu riječima - „Noge!

15 Usporediti: Genette, G. (2010) Die Erzählung, Stuttgart, str. 104-105.

16 Andrić, I. (1984) Jelena žena koje nema, Sabrana djela, Sarajevo, str. 15. 


\section{BERNARDA KATUŠIĆ}

Drž mu noge!“ (34) ili "Oprala sam ga [nož].“ (36). Nadalje, u upravnom govoru učestalo su prenesene naoko bezazlene šale, primjerice, Anikino slanje Nazifa po šećer (46) ili Taneta po limun (66), te redundantni razgovori kasablija, primjerice „dućanski razgovori“ koji su, kako ističe narator, uvijek ,ličili jedan na drugi““ (52, usp. i 51,55) ili razgovori Mihaila i Petra Filipovca, koji su bili uvijek istog sadržaja i koje je Petar Filipovac čak, kako podcrtava pripovjedač, govorio „uvek istim rečima“ (77). Navedenim ,ćaskanjima“ “ iz razonode suprotstavljeni su sadržaji prijetnji i kletvi, također izneseni u upravnom obliku, primjerice, Anikina prijetnja Ristićki i kletva Ristićkine snahe (48-50), koje posljeduju sudbonosno.

Osvijetljena navedenim kontekstom komunikacijska situacija između Anike i Mihaila koju pripovjedač opisuje pri sedmom navodu može se istovremeno čitati kao iznimno važna i nevažna, sporedna i krucijalna za daljnju sudbinu likova. Govoreći jedno, a iskazujući nešto posve drugo, ona razlistava još jedan daljnji semantički sloj.

\section{Govor likova}

Navedeno govorno razdvajanje, nemoć subjektova iskazivanja nerijetko je i eksplicitno problematizirano u tekstu. Traumatizirana stanja likova ponajprije su sugerirana njihovom nemogućnošću izricanja sebe samih i nesposobnošću verbalnog prodiranja u Drugog. Gotovo svi akteri prikazani su načinom kako govore, odnosno na suglasju / nesuglasju diskurzivnog iskaza i onoga što on pretendira i može iskazati. Tako je, primjerice, ,,poremećenost“" muškaraca koji su se okupljali u „Anikinu logoru“ ponajprije signalizirana njihovim verbalnim iskazima. Tane, ,jedan od najbeznadnijih i najrevnosnijih posetilaca“ (45), oslikan je time što „ništa ne govori“ te činjenicom da je, kad i progovori, „mislima [..] odsutan“ (45) ili da „odgovara tek pokatkad, kao kroz san“ (46); Niazif koji je bio „sasvim lud“ (46) opisan je govorom koji je „nerazumljiv[o] mumljanje“, ,gunđanje“, ,pevušenje i mrmorenje" (46); pop Vujadin karakteriziran je kao „neobično povučen i šutljiv“ (12), kao netko za koga su „svaki pogled i svaka reč izmenjeni s ljudima bili [...] muka i teret i bolno udvajanje“ (14); Lale kao netko tko je na sve „samo pevušio, izbegavajući razgovore“ (76); Anikina majka kao „ćutljiva i nedruževna“ (27); Mihailo kao netko tko na sve reagira „šalom ili ćutanjem“ i konačno Anika kao netko tko ,živi u ćutanju i prezire tuđu potrebu za govorom“ (62), kao netko tko na udvaranje momaka ovako reagira:

Ona ih je gledala sve podjednako i slušala mirno, najčešće i ponajduže Mihaila, ali sama nije odgovarala nikad ništa određeno. Govorila je prigušenim, mukim glasom gotovo ne 


\section{BERNARDA KATUŠIĆ}

otvarajući potpuno prava i puna, ali još malko bleda usta. Njene ponajviše jednosložne reči nisu ostavljale ni najmanjeg odjeka iza sebe, nego su se gasile i brisale potpuno čim ih izgovori. Tako je svakom ostajao u sećanju mnogo življe njen lik, nego njen glas i ono što je rekla. (30-31)

Navedena nemogućnost iskaza, dvije razine govora, diskurzivna i ona druga, nerijetko su tematizirane i izravno izrečene u samom tekstu. Tako je primjerice pop Vujadinov „razdvojeni“ način govora ovako predočen: „Ali dok bi tako razgovarao s njima, u sebi je pomišljao: evo, sad me uspoređuju sa pokojnim ocem i sa svima mojima." (15); Mihailo je na priče o Krstinu ubojstvu, koje je za njega, kako je istaknuto, bilo nesavladiva trauma o kojoj nikome nije govorio, „,na izgled“ reagirao „mirno“, „slušao je sve što se pričalo o napadu na Krstinice han, i sve što su ljudi tim povodom govorili o njoj“, i ponekad je čak ,nalazio snage da i sam kaže poneku reč“" (38); dok je Anika na Jakšina pitanja, prema iskazu pripovjedača, odgovarala „kao da ne misli na ono što govori” (70).

U interpretiranoj govornoj situaciji između Anike i Mihaila još naglašenije se problematizira rascijep između onog što se govori i onog što se iskazuje. Netom nakon relativno kratke govorne situacije slijedi dulji komentar pripovjedača fokaliziran Mihailovom perspektivom u kojem je detaljno opisano kako se osjeća Mihailo pri razgovoru s Anikom. Iz opisa pripovjedača razvidno je kako joj želi priopćiti nešto sasvim drugo te kako njezine riječi shvaća potpuno suprotno onome što one rijekom izriču (usp. 42-44).

\section{Govorna scena}

Traumatska stanja Andrićevih likova, njihova opterećenost „ostatcima realnog“" sugerirana su i najrazličitijim devijantnim načininima konfiguracije govorne scene na kojoj su verbalno djelatni. Tako oni umjesto s drugim govornim subjektima gotovo redovito razgovaraju ili sami sa sobom (pop Vujadin, usp. 14, 19, 20, 21, Mihailo, usp. 79, 80, 82), ili s predmetima (Anika, usp. 29), ili s više neizdiferenciranih subjekata. Posebno je indikativna u tom kontekstu komunikacijska situacija između Anike i Ristićke, majke jednog od redovitih Anikinih posjetitelja. Jednom prilikom, u naoko zatvorenom krugu, ,[z]imus, na jednoj daći, kad su se žene u jedan glas žalile na Aniku“ (48) Ristićka je izjavila „glasno i prkosno“: ,,- Bogami, ne dajte. Evo i ja imam sina, ali dok sam ja živa, on neće prekoračiti prag onoj rospiji.“ (48). Kao sve što se govorilo o njoj, Anika je doznala već sutradan za Ristićkine riječi i ubrzo joj odgovorila (čitatelj ne saznaje preko koga i kako): „,- Od danas pa do mjesec dana, doći će mi tvoj sin, hairlija, sa cijelim subotnjim pazarom u rukama; $i$ 


\section{BERNARDA KATUŠIĆ}

vidjećeš ko je Anika.“ (48). Očito prestrašena Anikinim riječima nato je reagirala Ristićkina snaha, potpuno bespomoćna, proklinjući Aniku u osami svoje sobe: „Dabogda, ženo, bijesna hodila, u lancima te vodili; dabogda se gubom razgubala; sama sebi dodijala; smrti željela a smrt te ne htjela!“ (49). I ta kletva došla je do Anike „već sutradan“ (50). (O načinu kako su informacije bile prenošene čitatelj ni ovaj put nije obaviješten.) Anika odgovara Ristićki i njezinoj snahi preko ciganke, koja na Anikinu izričitu naredbu, „odlazi na dno avlije“ kako bi ,izgovorila što je Anika rekla“" (50).

Iako je u navedenom razgovoru između Anike i Mihaila, barem na prvi pogled, sugerirana govorna scena u kojoj su stvoreni uvjeti „lokacije“ govornika u simboličkom poretku, pri detaljnijoj analizi, a ponajprije stavljanjem navedene govorne scene u cjelokupan narativni kontekst, na vidjelo izlazi suprotno. U atmosferi ,gde se tumači svaki Anikin korak i svaka njena reč prenosi od usta do usta“" (74) evidentno je da je svaki iskaz bez obzira na konfiguraciju govorne scene tek dio javnog prostora.

\section{Tko govori? Tko vidi?}

Promotrimo li navedenu dijalošku scenu između Anike i Mihaila s aspekta pripovjedačkog glasa (tko govori?) i modusa (tko vidi?) u Genetteovom smislu ona se razlistava daljnom značenjskom slojevitošću. ${ }^{17}$ Već površan pogled otkriva da je tekst s aspekta glasa realiziran heterodijagetskim i ekstradijagetskim pripovijedanjem, a s aspekta očišta nultom fokalizacijom, tipovima naracije koji prema Genetteu karakteriziraju „klasično“ pripovijedanje otjelovljeno u tzv. „sveznajućem“ pripovjedaču. Tako narativni signali teksta nerijetko sugeriraju da je u pozadini neimenovana i „bestjelesna“ pripovjedačka svijest reducirana na jedan glas koja sve pripovijedne niti čvrsto drži u svojim rukama i koji ,poput samog boga“ stoji nad svime. Sve upućuje na to da je posrijedi specifičan pripovijedni „svjedok“ koji realno ne može niti sve vidjeti niti sve čuti, a ipak pogađa sve misli, ,,prolazi kroz zidove“, vidi „s onu stranu ponašanja osluhujući tijelo i dušu“ odnoseći se prema svemu i svima potpuno jednako i ravnopravno (134). Međutim, već malo detaljnijom raščlambom izlazi na vidjelo da su navedeno ,jednoglasje“ i ,nulta“ točka motrišta samo okvirni da se orisana pripovjedačka instanca, kako po pitanju tko govori tako i po pitanju tko vidi, netom potom urušava sama u sebi.

Inicirana narativna strategija nagrižena je pukotinama već na početku teksta. U pripovijest nas uvodi pripovjedač u trećem licu

17 Usporediti: Genette, G. (2010) Die Erzählung, Stuttgart, str. 103-137 i 164-166. 


\section{BERNARDA KATUŠIĆ}

(heterodijagetski), „bestjelesno“ prisutan u predstavljenom dijegetičkom univerzumu (ekstradijagetski), naoko općom, neupitnom konstatacijom..$^{18}$ Međutim, već nekoliko redaka dalje, prestavljajući lik popa Vujadina, opisujući njegovo ludilo, kazivač umeće opasku „niko nije pravo ni znao“ (isto) blago ljuljajući naznačeni narativni habitus. Kako navedeni komentar nije jednoznačno ni apsorbiran, ni adiran inicijalnom pripovjedačkom glasu, te se istovremeno može nalaziti i unutar i izvan fiktivnog kozmosa, njime se relativizira prethodni iskaz i izravno potkopava zauzeta pozicija, te otvara mogućnost ucjepljivanja drugih glasova u početno zadanu naratološku perspektivu. Navodi koji slijede netom potom, poput „,̌̌ene“ su ,govorile“, „,seljaci“ su se ,žalili“", „stariji ljudi su pamtili““ (12) itd., kojima pripovjedač dodatno potkrepljuje/potkopava svoje iskaze, impliciraju posredništvo daljnih pripovjedača koji se kriju unutar zauzete pozicije. Promotrimo li Andrićev tekst s aspekta glasa na globalnoj narativnoj razini zauzeta pripovijedna pozicija dodatno se narušava. Narativni iskazi koji slijede multicipliraju broj glasova i pripovijednih razina, još ih naglašenije nerazmrsivo ispreplićući. Tako je pripovijedni tijek s vremena na vrijeme prekinut komentarima koji impliciraju dodatne glasove, kao primjerice, „niko se nije pravo nije sećao“ (27), „mnogo se od toga poboravilo, a mnoga je muka ostala zauvek neviđena i nekazana“ (45), „počeše da se sećaju“ (25), „mislilo se“ (23), ,govorilo se“ (47), ,ogovaralo se“ (47), ,prepričavalo se“ (51), „kažu“ (isto) itd. i(li) opaskama koje ukazuju na pripovjedačeve ,izlaske“ i ponovne „ulaske“ u dijegetski univezum, kao primjerice, „Evo kako je bilo.“ (25), „kao što smo videli““ (40) itd.

Glas i razina dodatno se roje u sižejnoj sekvenci u kojoj se prelazi iz priče o Aniki u priču o popu Vujadinu. Prije nego što je uspomena na popa Vujadina potpuno pala u zaborav ona je „izazvala (...) sećanje na druge nesreće i druga vremena“, „odavno zaboravljena“" (24), Anikina vremena. Suprotno dotadašnjim, „skupnim“ pripovjedačkim glasovima sakrivenim unutar zauzete pozicije, glas koji ovaj put iznjedruje dominantna narativna instanca osobno je specificiran i imenovan: „Mula Ibrahim Kuka izazva prvi sećanja na Aniku.“ (24). Za razliku od drugih pripovjedačkih glasova proizišlih iz dominantne kazivačke instance, Mula Ibrahim Kuka lik je koji se nalazi u dijagezi. Kako on, suprotno drugim akterima, u fiktivnom univerzumu nema nikakvu funkciju doli pripovjedačko-posredničku, prethodno zauzeti pripovjedački homodijagetski i ekstradijagetski stav propitan je s novog aspekta. Čitatelj o njemu i ne saznaje ništa osim da je ,voleo da izgleda učevan i tajanstven“, a da je u stvari bio „dokona dobričina i neznalica“, te da je ,živeo (...) od

18 Andrić, I. (1984) Jelena žena koje nema, Sabrana djela, Sarajevo, str. 11. 


\section{BERNARDA KATUŠIĆ}

ugleda i imetka svoga deda, čuvenog mutevelije Mula Mehmede“ (24). Međutim, ovi za fiktivni univerzum naoko beznačajni podaci ključni su za njegovo narativno posredništvo. Ibrahim Kuka svoja sjećanja „na druge nesreće i druga vremena“ koji čine sukus daljneg pripovjedačkog sadržaja potkrepljuje „kronikom“ koju je bilježio upravo njegov djed Mula Mehmed. Mula Mehmedov pripovjedački glas, koji isto tako nema nikakvu funkciju doli narativno posredničku $u$ fabularnom tijeku, koji je također reducirana na glas, ali sada na daljni glas glasa dodatno usložnjava i podriva naznačene narativne okvire. Čitatelj i o kroničaru Mula Mehmedu ne saznajemo također puno, uz krvno srodstvo s Ibrahim Kukom, tek da je bio „mudar“ i „književan“, da je ,živeo sto i jednu godinu“ (24) te da je bio vlasnik knjiga i spisa koji su preostali iza njega, „,nekoliko požutelih sveščica“ u koje je ,zapisivao sve što se dešavalo u kasabi i što je čuo da se dešava u svetu“ (24). I ove za fabularni tijek naoko beznačajne činjenice, motrene s narativno-posredničnog aspekta su nezaobilazne. Upravo u tim „,požutelim sveščicama“ Mula Mehmed zabilježio je i ,priču o Aniki“ koju uvodna pripovjedačka heterodijagetska i ekstradijagetska instanca prenosi u cijelosti odvajajući i ističući je od ostalog teksta navodnicima.

„Te iste godine pronevaljali se u kasabi jedna žena, vlahinja (Bog neka pomete sve nevernike!), i toliko se ote i osili da se njeno nevaljalstvo proču daleko izvan naše varoši. Mnogi su joj muškarci, i mlađi i stariji, dolazili, i mnoga se mladež tu ispoganila. A bila je metnula i vlast i zakon pod noge. Ali se i za nju nađe ruka, i tako se ona skruši po zasluzi. I svet se opet dovede u red i priseti božjih naredaba.“

Mula Ibrahim pročita na dućanu taj zapis, i najstariji ljudi počě̌e da se sećaju onoga što su slušali nekad u detinjstvu iz razgovora starih ljudi; $i$ tako se saznade za davno zaboravljena Anikina vremena. (25)

Mula Mehmed, akter bez osobnih karakteristika, sveden na funkciju pripovjedača-posrednika, vlasnik ,dokumenta“ koji figuriraju kao svojevrsni pratekst i potka Andrićeve pripovijest potiče na „sjećanje“ i ,pričanje“ drugih glasova i zatvara tako krug pripovjedača te nas ponovno vraća početnoj narativnoj instanci umnažajući broj pukotina stubokom još jednom.

Ne samo kategorijom glasa nego i kategorijom modusa Andrićev tekst je iznimno višeslojan. Zauzeto „nulto“ (,sveznajuće“) pripovijedanje potkopava se ponajprije stoga jer naznačena pripovijedna svijest, gotovo paradoksalno, vlastite stavove iznosi vrlo rijetko ili gotovo nikako. Nestabilnost je indicirana i „tehnikom“ na kojoj heterodijagetski i ekstradijagetski pripovjedač temelji svoje iskaze. Glasovi koje on prikuplja i na koje se 


\section{BERNARDA KATUŠIĆ}

poziva su ponajprije, kao što je istaknuto, sjećanja i razgovori neidentificirang "naroda". Naznačena vizura poljuljana je i time što se narator uz navedeni ,usmeni“, „neprovjerljivi“ tip izvora istovremeno poziva i na pisanu, ,dokumentarnu“ građu. „Sveznajuća“ pozicija uzdrmana je i uvjerljivošću pripovjedačevih pojedinačnih iskaza. Tako primjerice on na jednom mjestu apodiktički tvrdi: "U kasabi se sazna o svakome sve; nema tajne ni u duši ni na telu.“ (50), kako bi, potom, samo nekoliko stranica istom nepobitnom intonacijom pobio rečeno: „Ali u svem tom zlu i opštoj patnji zbog Anike, bile su dve patnje koje ni u toj kasabi, gde se sve vidi i čuje, niko nije znao ni naslućivao. Bila su dva čoveka koji su patili svaki za sebe (...),, (75). I konačno, urušavanje pripovjedačeve početno orisane „nulte“ pozicije, njegovo stalno balansiranje između ,sveznanja“ i ,neznanja“, možda se najbolje može ilustrirati činjenicom da njegovo „sveznanje“ nije ravnomjerno podjeljeno. Tako centralni narativni glas o nekim likovima zna najskrovitije tajne (primjerice o pop Vujadinu, Mihajlu), o čemu i izvještava čitatelja, dok o unutarnjem životu, o tome što osjećaju i misle drugi, k tomu također ključni likovi (primjerice Anika, Lale) ne zna, ili preciznije ne izvještava, ništa. Tehnika narativne šutnje, odnosno princip tajanstvenosti, koje smo istakli pri analizi fabularnog tijeka, nameću se i po pitanju fokalizacije kao središnji rekviziti.

Međutim, kako se radi o iznimno osebujnoj narativnoj strategiji, o čemu će još biti riječi, Andrićevu tehniku tajnovitosti nije moguće ukalupiti u niti jedan od Genetteovih tipova „tajanstvene“ fokalizacije. Andrićev fokalizator ne daje niti manje (paralipsa), niti više (paralepsa) ${ }^{19}$ informacija nego što je u početku dozvoljeno. Andrićev postupak nije moguće uklopiti ni u ,polimodalnost ${ }^{\text {"20 }}$, narativni kalup koji Genette motri kao iznimku. Iako je evidentno da i Andrićeva narativna strategija počiva na kombinaciji više navedenih modela, na svojevrsnoj „,verbalnoj igri“ koja „potresa čitavu logiku pripovijednog prestavljanja“ (128), ona ne funkcionira prema principu „dvostruke“ ili „višestruke“ fokalizacije, nego na mnogostrukosti proturječnih perspektiva, na estetskoj praksi koja ne samo kombinira, nego prije svega vrlo latentno i višestruko iznutra podriva više narativnih programa.

Iz rečenog proizlazi da je, za Andrićev fikcionalni svijet, posredovan pripovjedačem koji stalno balansira između sveznanja i neznanja govora i šutnje, laži i isitine, punog i praznog govora, uz ,gramatičku“ narativnu raščlambu važno i u kakvom su

19 Termin paralepsa Genette koristi, bez dodatnog raščlanjenja, kako za kategoriju vremena tako i za fokalizaciju (usp. Genette, G. (2010) Die Erzählung, Stuttgart, str. 29-30 i 125).

20 Isto, str. 127. 


\section{BERNARDA KATUŠIĆ}

međusobnom odnosu govornici te tko su oni i sa „sadržajnog“ aspekta. Shodno tomu značajni od pitanja tko govori? i tko vidi?, nameće se „odnos između vizije, instance koja to vidi i onog

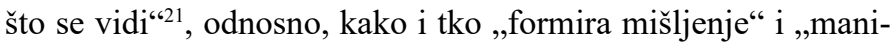
pulira" njime (110), a time i tko je uopće taj tko govori, njegov socijalni identitet, njegova pouzdanost, otvorenost, svjetonazor, te širi društveno-politički kontekst.

U takvom fiktivnom kozmosu u kojem se, $\mathrm{s}$ jedne strane, $\mathrm{u}$ jednom govoru nerazmrsivo prepliću najrazličitije sfere nadležnosti i time najrazličitje oblikovani svijetovi vrijednosti koji oponiraju jedan drugome, u govornoj sceni koja funkcionira kao svojevrstan virtualni prostor mnoštva neidentificiranih sugovornika čije je pojedinačne glasove nemoguće raščlaniti i identificirati nemoguća je realizacija osobne komunikacije. U tom kontekstu motren navedeni razgovor između Anike i Mihaila može se tumačiti kao neuspješni pokušaj hrvanja sa svijetom u kojem se nalaze, nastojanje prodiranja do ljubećeg Drugog ,punim“ govorom i jezikom žudnje. Pođemo li, s druge strane, ne od osobnih sudbina $\mathrm{i}$ iskaza koje tekst izravno iznosi, nego povežemo li tekstualne taktike sa širim društveno-kulturnim kontekstom i autorskom pozicijom otvaraju se nova tumačenja.

\section{Tko je veliki Drugi}

Evidentno je, na osnovi rečenog, da su traumatska iskustva pojedinca u Andrićevu tekstu ponajprije sugerirana načinom iskaza. Međutim, ostaje otvorenim koliko su njihova traumatska stanja uzrokovana tipom „malog“ ili “velikog Drugog”? Odgovor na navedeno pitanje, paradoksno, otvara daljnje, koje je nerijetko i bilo predmet kritike Lacanove teorje, tko je „veliki Drugi“? Govoreći o "velikom Drugom” kao simboličkom poretku koji postoji prije pojedinca samog, implicira li Lacan njime neku neidentificiranu, ahistorijsku kategoriju samog označitelja ili političke oblike specifičnih, društveno stvorenih interesa i institucija. ${ }^{22}$ Kao što je već istaknuto, Andrićeva pripovijest Anikina vremena iznimno je slojevito literarno štivo u kojem su uzroci traumatskih stanja znanto više sugerirana, nego izravno i jednoznačno izrečeni. Raščanjivanje i interpretacija narativnih

21 Bal, M. (1985) Narratology. Introduction to the Theory of Narrative, translated by C. V. Boheemen, Toronto, Buffalo, London, p. 104.

22 Svakako jedan od prvih koji se suprostavio Lacanovom ahistorijskom poimanju subjekta i žudnje, njegovoj tezi da je sebstvo uvijek otuđeno od vlastite povijesti, oblikovano kroz drugost te kao takvo ubačeno u simboličku mrežu je Foucault (već u usp. Foucault 1981). Diferenciranje postlakanovske misli prelazi okvire ovog rada, ističem samo nezaobilazna istraživanje logike žudnje kao društvenog pokazatelja posebice u radovima Althussera, Žižeka i Laplanchea (usp. Elliott, A. (2015) Psychoanalytic Theory: An introduction, London: Palgrave, str. 100-124). 
informacija koje tekst ekplicitno iznosi različitim teorijskim alatkama lako bi se mogla zaplesti u kontradiktornim tumačenjima. Promotrimo li logiku žudnje kao društveni pokazatelj, zapitamo li se mogu li subjektivna izobličenja, premještanja i potiskivanja funkcionirati, i kako i koliko, kao simptomi društvenog i kulturnog polja, pokušamo li razotkriti povijesne uvjete u kojima nastaju određeni fenomeni i subjekti, evidentno otvaramo novo semantičko polje Andrićeva teksta.

\section{Anikino vrijeme}

Kao što djelomično sugerira i naša interpretacija, u pripovijesti Anikina vremena dominiraju osobne sudbine i iskustva (Anikina, Mihajlova, Jakšina). Navedenu konstataciju moguće je potkrijepiti i načinom kako je u djelu oblikovana vremenska instanca. Ona je u Andrićevu cjelokupnom opusu, a u ovom tekstu osobito, kako s apekta narativnih strategija tako i s obzirom na društveno-povijesni kontekst, iznimno kompleksno i višeslojno konfigurirana. (Detaljna analitička raščlamba nadilazila bi okvire zadanog prostora). Krajnje pojednostavljeno, s obzirom na sudbinu lika, odnosno skupinu likova koje sižejna okosnica prati, moguće je izdvojiti tri vremenske linije.

Prva vremenska okosnica prati propadanje obitelji Porubović kroz četiri posljednja (muška) pokoljenja: pop Vujadin, pop Kosta (otac), Jakša zvan Đakon (djed) i Melentije (pradjed). Nakon priče o рори Vujadinu s kojom počinje tekst retrospektivno se prestavljaju ostali članovi obitelji (u središtu je priča o Jakši). Usprkos evidentim indikacijama na vremenske realije - priča o рори Vujadinu počinje, kao što eksplicitno stoji u tekstu „šezdesetih godina prošlog stoljeća“ (11) i završava njegovom smrću (23), učestalim isticanjem pripadnosti obiteljskom stablu, te činjenici da su sižejna i semantička linija motivirane krvnim srodstvom, tek je vrlo pažljivim čitanjem moguće pratiti razlistavanje obiteljske loze i indiciranog vremenskog ritma. Kako su podaci koje dobivamo o pojedinim članovima obitelji distribuirani u različitim (često neočekivanim) sižejnim isječcima, tek je neizravnim pripovjedačkim signalima moguće rekonstruirati navedeni generacijski slijed. Primjerice, da je Jakša Vujadinov djed navedeno je tek, kao uzgred, u priči o pop Vujadinu, koja otvara tekst, dok u priči o Jakši, s kojom pripovijest završava, navedena rodbinska relacija nije spomenuta. Zbunjuje i to da je Jakšin nadimak Hajduk Đakon naveden samo pri prvom spomenu njegova imena. Tek iznimno pažljiv čitatelj prepoznat će i Melentija kao Jakšina oca. U tekstu je samo dva puta navedeno da se Jakšin otac zvao Melentije, u narativnom segmentu u kojem je on tek uzgred spomenut (24), te u navodu kronike (25), dok u svim ostalim sekvencama, u kojima je Melentije jedan 


\section{BERNARDA KATUŠIĆ}

od ključnih aktera, primjerice, u dijelovima u kojima se opisuje njegov sukob s Anikom, ni u jednoj situaciji nije naveden punim imenom nego tek kao „dobrunski proto“. Već spominjanom tehnikom tajnovitosti koja izrečenim smjera na nešto drugo paradoksno zamagljujući upravo eksplicitnim navođenjem Andrić se evidentno koristi i pri konfiguraciji vremena. (Iscrpna analiza značenja tako prestavljenih vremenskih signala također bi nadilazila okvire ovoga članka.) Zadržimo li se tek na značenju istovremenog isticanja i zamagljivanja identiteta muških nasljedavatelja navedenog obiteljskog stabla, jedna od semantičkih konotacija navedene pripovijedne tajnovitosti svakako je značenjsko nijansiranje druge vremenske linije - priče o Aniki.

Narativno-tehnički motreći, vrijeme te priče umetnuti je segment u vremenski slijed obitelji Porubović, što je vidljivo iz sljedećeg navoda: „Tako se, u čestim razgovorima o porodici Porubovića, dolazilo ne samo do pop-Vujadinova oca i deda nego i do njegova pradeda Melentija, a po njemu i do Anikinih vremena." (24). Vrijeme priče o Aniki, evidentno centralna vremenska linija pripovijesti, što je sugerirano i naslovom, naoko je krajnje reducirano i pojednostavljeno. Grubo govoreći, ono prestavlja samo jedan isječak iz njezina života i traje od trenutka kada se ona „obznanila“ kasabi do njezina kobnog umorstva. Tako postavljeno i ono odiše posebnom tajnovitošću. Njegova zagonetnost ponajprije počiva na činjenici da je ono istovremeno „zatvoreno“ i „otvoreno“. Kao što je eksplicitno naznačeno u tekstu, i prije i poslije Anike kasabom su „harale“ / će „harati“ žene slične njoj. Dvjema „umetnutim“ pričama o sličnim ženskim likovima, koje se retrospektivno pomiču u daljnu prošlost i sukcesivno krate u vremenu u kojem su ispripovijedane, pričom o Tijani koja je „harala“ prije „dobrih sedamdeset godina“, a koja je prestavljena na nepune dvije stranice (51), te pričom o Saveti, u kojoj vrijeme u kojem je junakinja živjela nije naznačeno, a koja je iznešena tek u jednom rečeničnom umetku (77), vrijeme se „otvara“" nesagledivoj prošlosti. S druge strane, činjenicom da kasaba netom nakon Anikine smrti, vidno oporavljena, živi daljnim uobičajenim životom, što implicira da bi se nakon nekog vremena ponovno mogla pojaviti kakva kao Tijana, Saveta ili Anika, a što je eksplicitno i izrečeno komentarom pripovjedača - „Ako se opet pojavi neka takva ili slična napast - a pojavit će se kad-tad - kasaba će se opet boriti i nositi s njom dok je ne salomi, ne pokopa, i ne zaboravi.“ (88) - vrijeme se otvara nesagledivoj budućnosti.

I treća linija je konkretno društveno-povijesno vrijeme koje natkriljuje sve u dijagezi prestavljene događaje, akcije, osobine, misli i riječi aktera. Na prvi pogled, pripovijedne indicije koje upućuju na konkretan historijski kontekst iznešene su u iznimno 
šturom obliku i potisnute u pozadinu. Stječe se dojam da je sve što bi moglo upućivati na povijesni kontekst uzgredno spomenuto funkcionirajući tek kao okvir, svojevrsna narativna kulisa prestavljenih događanja. Vremenske „realije“, što je bilo i polazište naše analize Andrićeva teksta, nisu aktivno uključene u fabulativni tijek, niti je on njima motiviran. Promotrimo li i narativne indicije o konkretnom povijesnom vremenu ne s aspekta što one iskazuju, nego što prešućuju i na što ukazuju, razodijenemo li i njihovo tajnstveno ruho i one zablistaju značenjskom slojevitošću i višeznačnošću.

Ponajprije, narativne indicije signaliziraju da su prestavljeni događaji situirani u vremenu turske i austrijske (pred)okupacije Bosne. Signalizirajući imerijalistički društveni poredak navedena narativna faktografija o povijesnim realijama ujedno detektira da unutar vladajućeg sistema vlasti koegzistiraju i različiti oblici otpora koji posljeduju daljnim oblicima (para)vlasti, svojevrsni sustavi vlasti unutar vlasti. Navedeni ustroj moći dade se iščitati iz načina kako su karakterizirani neki od autoriteta vlasti pravoslavne crkve. Primjerice, Kosta kao osoba koja je i „među pastvom i među Turcima“" imala ,iskrenih prijatelja i velikih neprijatelja“ (13) i koja je, usprkos tomu, živjela lijepo i s „narodom i s Turcima“ (12). Navedeno razlistavanje društvenog sustava moći u više podsistema najizravnije izriče Anika u pismu upućenom Jakšinu ocu: „Ti si proto dobrunski, a ja džizlija višegradska. Nurije su nam podijeljene, bolje ti je da ne diraš u ono što nije tvoje.“ (63-64). Da je društveno uređenje sadržano od više (potencijalno konkurentskih / oponentnih) krugova vlasti odaje i to što su gotovo svi akteri eksplicitno karakterizirani i prema nacionalnoj i(li) religioznoj pripadnosti. Štoviše, njihova narodnost $i($ li) vjeroispovijest nerijetko su istaknuti u sižejno i semantički posebice nabijenim trenucima. Tako je već u spomenutoj „kronici“ koja nagovješćuje priču o Aniki naglašeno da je ona „vlahinja“ (25); nakon što se Jakšin otac, kao poseban crkveni autoritet, žalio na Aniku Alibega je naredio starješini višegradskih zaptija ,da ode do te vlahinje“ (57); pri prvom susretu Alibega i Anike pripovjedač Alibegino oduševljenje ovako komentira: „Šta je moglo da spreči Turčina ako ne Anika sama?“ (62) itd.

Narativne indikacije o konkretnom društveno-povijesnom kontekstu razgolićuju i pripovjedačev/autorov stav prema navedenim političko-upravnim ustrojima. Tako je austrijska vlast percipirana kao moderna (nova, nepoznata i zanimljiva), a turska je prestavljena kao dugovječna (sigurna, gotovo ležerna u svojoj snazi). Dok se u načinu kako je prestavljena austrijska vlast dade nazrijeti izvjesna blagonaklonost, turska vlast viđena je vidljivo negativnijom optikom. Navedena percepcija vlastodržaca naj- 


\section{BERNARDA KATUŠIĆ}

izravnije se iščitava iz njihova odnosa prema narodu. Tako je, primjerice, austrijskim „vlastima“ bilo „neprilično“ (23) vidjeti uplakane žene zbog ludog Vujadina kada je on posljedni put prolazio kroz kasabu, dok su turske vlasti na istrazi o Anikinu umorstvu svjedoke, njene sluškinje, tukli ,bez potrebe, jer je svaka od njih govorila i bez toga istinu“ (88).

Takvo se viđenje Istoka i Zapada, barem na prvi pogled, ne uklapa u način kako je prestavljana Otomanska imperija u Andrićevu opusu. U usporedbi s drugim tekstovima iste tematike, ponajprije u romanima Na Drini ćuprija i Travnička hronika, kao što je $\mathrm{u}$ kritici nerijetko isticano ${ }^{23}$, u kojima je turska vlast prestavljena u ,njenom suštinskom karakteru“ i ,punoj realnosti“ njezine „svireposti“ ${ }^{24}$ u pripovijesti Anikinim vremenima ona je viđena na posve drugi način. Promotrimo li otomansku imperiju u kontekstu navedene tehnike narativne tajnovitosti i šutnje u kojoj upravo ono što nije izrečeno dobiva na značaju i ona se pokazuje u drugom svjetlu.

\section{Tajanstvena ruka}

Kao što je već istaknuto, pripovijest Anikina vremena prstenasto je strukturirani tekst koji se sastoji od nekoliko relativno autohtonih fabularnih linija. Priču o Aniki moguće je motriti i kao jednu od narativnih cjelina, ali i kao centralnu pripovijest, koja natrkiljuje sve ispripovijedano. Uzmemo li je kao priču-središnjicu, najkraće rečeno, njen fabularni tijek satkan je od četiri razvojno piramidalne, gotovo aristotelovski klasične (uvod, komplikacije, kulminacija, obrat, katastrofa), sižejne sekvence: 1. Anikin ulazak u svijet odraslih; 2. rast / kulminacija Anikine moći; 3. borba kasabe protiv Anikine prevlasti; 4. Anikin pad i smaknuće. Navedene etape fabularne linije naglašene su i u

23 Iako je odnos Istok / Zapad kao tipičan topos Andrićeve poetike u kritici iscrpno tumačen (usp. između ostalog Sekulić, I. Istok u pripovetkama Iva Andrića, u: Kritičari o Ivi Andriću, ur. Milanović, B. (1977), Sarajevo, str. 50-59; Gligorić, V. Romani Ive Andrića, u: Kritičari o Ivi Andriću, ur. Milanović, B. (1977), Sarajevo, str. 181-199; Peleš 1979, Ređep, D. (1981) IvoAndrić: Između Istoka i Zapada (varijacija na temu: treći svet), u: Delo Ive Andrića u kontekstu evropske književnosti i kulture, Beograd, str. 517-525; Hawkesworth, C. (1984) Ivo Andrić: Bridge between East and West, London; Wermuth-Atikson, J. (2005) Between Orient and Occident: Damned Yard in the Context of European Aesthetics, Serbian Studies, br. 2, str. 295-30; Škvorc, B. Okcident i Orijent: Osmajnlije i islam prema kršćanstvu. Ili: Andrićevi franjevci u pričanju (kolonijalne) priče, u: Ivo Andrić - književnik $i$ diplomata u sjeni dvaju svjetskih ratova (1925-1941), ur. Tošović, B. (2012), Graz, str. 311-341); Autorovo prestavljanje ljubavne žudnje u rascjepu dvaju suprostavljenih svjetonazora do sada nije bilo problematizirano. Detaljna raščlamba navedenog toposa $u$ dosadašnjim kritičkim čitanjima nadilazi okvire teme ovog rada.

24 Gligorić, V. Romani Ive Andrića, u: Kritičari o Ivi Andriću, ur. Milanović, B. (1977), Sarajevo, str. 182. 
Mula Mehmedovoj kronici. Već u njoj se nagovještava / ističe da se prije nekog vremena "jedna žena, vlahinja“, ,pronevaljalila“" te da je „ratovala sa celim hrišćanskim svetom i svima svetovnim i duhovnim vlastima“, kao i to da joj je pošlo za rukom metnuti ,i vlast i zakon pod noge“, te da se, naposljetku, i za nju našla „ruka“ koja joj je „posekla kolena“ i „skrušila“ je "po zasluzi“ (25-26). Pripovijedni sadržaj koji potom slijedi tek podrobnije izvještava o svemu navedenom usredotočujući se posebice na to s kim se Anika bori i tko je tajanstvena „ruka“ koja ju je uništila.

Borce protiv Anikine (pre)vlasti, prema moći koju uživaju u prikazanom imperijalističkom društvenom poretku, moguće je podijeliti u pet hijerarhijsko-gradacijskih krugova. Žene, najniži sloj u patrijahalnom društvenom poretku, predvođene starom Ristićkom, bile su prve, koje su reagirale na Anikino bezumlje. $\mathrm{U}$ trenutku kada Anikina snaga evidentno kulminira, kada se u kasabi normalno stanje stubokom izokreće, kada su svi muški stanovnici ,podlegli“ Anikinoj sili i „svet“ poče „da se podsmeva“ (47) ne onima koji su je posjećivali, nego onima koji nisu, „[s]amo su žene bile složno i ogorčeno protiv napasti sa Mejdana i borile se uporno, bezobzirno, ženski, bez mnogo smisla i razmišljanja“" (48). Netom potom formira se drugi krug boraca, muškarci, protiv Anikine anarhije, predvođen gazda Filipovcem. Treći krug, hijerarhijski nadređeniji obama prethodnima, prestavlja pravoslavna $c r k v a$, predvođena dobrunskim protom koji, nakon što je iscrpio sve mogućnosti kako bi svog sina Jakšu odvratio od Anike i doveo kući, ali kako ništa nije urodilo plodom, odlučio obratiti se višegradskom kajmakamu, tadašnjem prestavniku noseće političke vlasti. Međutim, kao što potvrđuje više različito fokaliziranih narativnih iskaza, ni to nije pomoglo. Prema Anikinim riječima, ona je kajmakamu ,otpasala sablju kao djetetu“, te joj je on „onako star držao legen i peškir“ (63-64), što je posljedovalo time da je ona, kako navodi gazda Petar, postala „ovoj kasabi i paša i vladika“ (77), koja stoga, kako izvješćuje „sveznajući“ pripovjedač, može u kasabi, koja je od tada ,živela u strahu i snebivanju, u potpunom rasulu i bezvlađu“, izvesti „sve što zamisli“ (72-73). Nakon ovog Anikinog trijumfa ostala je tek ,božja ruka“ (64) koja je mogla pomoći kasablijama.

Dok su krugovi koji se bore protiv Anike, kao i to u kakvom su odnosu moći s obzirom na vladajući ustroj, relativno jasni, pitanje tko je ta „ruka“ koja ju je usmrtila gotovo u potpunosti, kao što je već istaknuto, kako za čitatelja tako i za sve aktere fiktivnog kozmosa, ostaje zamagljeno. Tehnika istovremenog korištenja „govora“ i „,onog drugog govora“, odnosno govorenje jednog, a osvjetljavanje drugog u načinu signaliziranja i detektiranja „ruke“ koja je usmrtila Aniku korišteno je s najrazličitijih 


\section{BERNARDA KATUŠIĆ}

narativnih aspekata i posebno je zanimljivo. Tajna kao postupak u svršetku romana pokazuje se u najjasnijem i najusijanijem obliku.

Prvi koji bi prema narativnim signalima mogao biti ta „ruka“ koja je usmrtila Aniku je Mihailo. Već iz naoko sporedne verbalne reakcije, u jednom od prethodno spominjanih, čestih i vrlo jednoličnih razgovora Mihaila i gazde Petra Filipovca, iz Mihailova komentara: „doći će i njoj jednom kraj“ (77), može se naslutiti njegova namjera uništiti Aniku. Daljnjim narativnim iskazima čitatelj dobiva potkrepu navedenim slutnjama. Mihailove namjere posebice se potvrđuju u poduljem pasusu, u kojem ,sveznajući“ pripovjedač „unutarnjom“ fokalizacijom povjerava čitatelju podatke koji svim drugim akterima ostaju zamagljene izvještavajući o Mihailovim planovima i pripremama za posljednji susret s Anikom. Posebice čitatelju skrovito povjerena infomacija da je Mihailo za to jutro pripremio ,veliki nož“ istovremeno sakriva i otkriva tajanstvenost Mihailovih nastojanja. Iz događaja koji su potom prestavljeni razvidno je, da Mihailo pri susretu s Anikom u njezinu domu nalazi njezino mrtvo tijelo te da njagova nije ta „ruka“ koja je usmrtila Aniku. Kako i ovaj podatak do kraja ostaje poznat tek pripovjedaču izvjestitelju, Mihailu i čitatelju i on odiše posebnom tajnovitošću koja istovremeno zamagljuje i rasvjetljava. Usredotočimo li se na druge infomacije koje su u navedenom narativnom segmentu povjerene čitatelju navedena tehnika još je izravnija. Promotrimo li, primjerice, Mihailove motive zbog kojih je kanio usmrtiti Aniku, kako njegove namjere tako i sugerirana pripovijedna tajnovitost obasjavaju se u novom svjetlu. Iz Mihailovih razmišljanja razabire se da je ljubavni doživljaj s Krstinicom i ubojstvo njenog muža u kojem je on slučajno sudjelovao, a od kojeg je prošlo osam godina, okidač Mihailovih namjera. Već navedenim prinicipom svojevrsne lančane tajnovitosti postaje zorno da Mihailova namjera i nije obračunati se samo s Anikom nego i s Krstinicom, ali i sa svim „malobrojn[im] i bedn[im] ženama koje je u ovih osam godina sreo“ (79). Odnosno, slijedeći daljnje narativne informacije iznešene istim principom (de)šifriranja tajanstvenosti koja postaje još zagonetnija, da je najvjerovatnije njegova namjera bila nakon ,mnogostrukih i mračnih mučenja, koja je poznavao u dugogodišnjoj samoći“ obračunati se sa „samim sobom“ (80). Povjerna tajnovitost nadaje se još zagonetnijom i sekvencom $u$ kojoj se Mihailo evidentno oprašta od nekoga (Anike, Krstinice, sviju žena ili sebe sama?) ponavljajući nekoliko puta riječ „zbogom“ $(82,83)$ i rečenicu „Sve je ovo život“ $(83,84)$. San kao inicijalna i finalna točka Mihailove akcije, u zbunjujuće višeznačnom obliku istaknut na kraju odjeljka još jedan put - ,,iznenađen, zbunjen, kao da u nekom čudnom snu sniva drugi još čudniji san“" (86) - boji sve rečeno daljnom tajnovitošću. 
Prema daljnim izravnim narativnim signalima drugi Anikin potencijalni ubojica mogao bi biti Lale. Uvlačenjem novog lika u igru odgonetavanja tajne, ne samo zagonetnost pitanja tko je ta „ruka“ koja je usmrtila Aniku, nego i tajanstvenost pripovjednog modusa, osvijetljeni su s novog aspekta. Identičan „,sveznajući“ pripovjedač istom nutarnjom, Mihailovom, fokalizacijom u jednakoj narativno krajnje skrovitoj atmosferi sumnjiči Anikina brata Lalu kao ubojicu. Tajnovitost je potencirana i time što isti, neočekivano izokrenuti narator, u vrlo kratkoj sceni, još nekoliko puta mijenja zauzeti pripovjedački habitus. Već navodeći drugu rečenicu „sveznajući“ pripovjedač iz pozicije nutarnje fokalizacije s likom-akterom prelazi u neočekivani imperativnokondicionalni izričaj izvještavajući da Mihailo „razmišlja“, tj. da se njemu ,čini“ da bi se Lale trebao obračunati s Anikom. "Činilo mu se da bi on kao brat Anikin trebalo da sve to uvidi i oseti, i da je on sam razoruža i upokori i, ako treba, ukloni.“(82). Tek nekoliko redaka potom narator zauzima drugu, objektivnu perspektivu i izvještava: „Prolazi pored Lalove pekarnice, ali niko ne peva iz nje; kao nikad u ovo doba dana, ona je zatvorena“ (86). I naposljetku iz pozicije svjedoka koja se nadaje ključnom u kontekstu postavljenog pitanja (tko je ubojica?) pripovjedač zaključuje:

Čim je stupio na kućni prag pogled mu pade na ognjište. $U$ tankom pepelu ležao je bačen crni pekarski nož, krvav do drška. To je onaj isti nož koji je toliko puta video u Lalovim rukama dok je s njim razgovaro u pekarnici. (86)

I konačno, odgovor na pitanje tko je tajanstvena ,ruka“ koja je Aniki ,posekla kolena“ i ,skrušila“ je ,po zasluzi“, na izravnoj diskurzivnoj razini, čitatelj dobiva još jednom, ne više u povjerljivo skrovitoj nego uvjerljivo otvorenoj pripovijednoj poziciji. Početni, „sveznajući“ pripovjedač, na kraju pripovijesti, „nultom" fokalizacijom, odjevena u autoritet vlastodršca i zakonodavca, zaključno izvještava, ne tajeći ništa niti pred čitateljem niti pred svim akterima u dijagezi, o istrazi koju je provela tadašnja vlast o počinjenom zločinu. Već činjenica da je Hedo vodio istragu, osoba bez zanimanja za bilo kakvu pravdu i bez imalo osjećaja za „vlast i silu“ (58), čovjek koji je vjerovao da se pravda rješava sama od sebe, ,,a kad je u neki spor ili zločin bila umešana žena, ta njegova pasivnost pretvarala se u potpunu ukočenost" (59) potkopava vjerodojstojnost naznačenog autoritativnog diskursa. Autentičnost iskaza poljuljana je i ispitivanim svjedocima, Anikinim sluškinjama, s kojima je ona „malo govorila i nikad im nije otkrivala svoje namere“ (88-89). Princip lančanog (de)šifriranja tajanstvenosti otvaranjem novih zagonetki ističe se i izravno u dijagetskom univerzumu izričenim pitanjima poput: „Zašto je Anika zvala brata, s kojim se inače 


\section{BERNARDA KATUŠIĆ}

nije viđala, to isto jutro kada je trebalo da joj dođe i Mihailo? Da li je bio slučaj? Ili je spremala neku zamku i iznenađenje? I koji je od njih dvojice mogao ubiti Aniku?“ (88-89). Dvosmislenost kulminira još jednom na kraju pasusa pripovjedačevim naoko jednoznačnim zaključkom: „Sve je bilo nejasno, zamršeno i bez ikakva izgleda na rešenje.“( 89$)$.

Paradoksno, umjesto zatvarajući postavljenu enigmu tko je „tajanstvena ruka“, navedeni zaključak u nedogled je otvara. Prema njemu ubojica bi mogli biti ne samo dvojica izravno osumnjičenih, nego svi spominjani krugovi vlasti i borci s Anikom, kao i svi akteri dijagetičkog univerzuma, te naposljetku, i Anika sama.

Analiziramo li tajnu fabularnog zapleta s drugog aspekta, ne s obzirom na to na što narativni signali iskazuju, nego na što ukazuju, ne ono što je izravno rečeno, nego ono što je prešućeno i mišljeno, aktualna vlast je prva koju sumnjičimo. U različitim krugovima koji se bore protiv Anikine anarhije, kako smo istakli, njoj je dodjeljen poseban dignitet. Osmanska imperija prestavlja vrhunac hijerarhijske piramide moći, najsnažniju ,ovozemaljsku“ silu, što je, kako je već istaknuto, više puta eksplicitno i izrečeno u fiktivnom univerzumu (usp. 63-64, 72-73, 77). To potvrđuje i narativna informacija da turska vlast vodi istragu o Anikinu ubojstvu i zaključuje akt. S druge strane, činjenica da je i Alibega kao najveći prestavnik turske vlasti podlegao Anikinim čarima baca novo značenje na to kako i koliko je vlast umješana u Anikino smaknuće. Evidentno, on se razlikuje od svih drugih posjetitelja. Prvo, on je jedini koji nije traumatiziran, iako je fizički atakiran, što je vidljivo iz njegova ponašanja. Iako je nejasno zašto Alibeg prestaje posjećivati Aniku, očito je da to nimalo ne narušava njegov uobičajeni životni ritam, on i nadalje ,,provodi večeri u svojoj bašti pored Drine i pije s prijateljima“, „kockaju se, šalju vojnike da puštaju niz vodu žute tikve i gađaju u njih kao u nišan“, ,,dovode Cigane svirače“ itd. (73-74). Evidentno je da ga ni Anikino pogubljenje nije uznemirilo. Nakon njezina umorstva on nastavlja ,svoj život od pre i od uvek, na zadovoljstvo sebi i drugima“" (89). Njegova uloga bitno je drugačija od sviju drugih Anikinih „obožavatelja“ i stoga jer njegove posjete, kao što je istaknuto, označavaju kulminaciju njezine moći, dok prestanak njegovih dolazaka njezin nagli završetak. Dok je vrhunac Anikine moći izravno istaknut $\mathrm{u}$ tekstu, njen neočekivani pad sugeriran je ponajprije njenzinim reakcijama. Na Alibegovu odsutnost i šutnju Anika reagira neočekivanom ukočenošću i još naglašenijom šutnjom. Ona u to vrijeme ne radi ništa, nikoga ne prima. Posebno indikativno je da se baš u takvoj situaciji oglašava već spomenutom rečenicom - „Osevapio bi se ko bi me ubio.“- jedinim izravnim iskazom o sebi samoj, a koji znakovito prenosi neki nepoznat Turčin. Kao 


\section{BERNARDA KATUŠIĆ}

i izravne narativne informacije, tako i navedene akcije i reakcije likova još jednom (de)šifriraju sugeriranu tajanstvenost Anikina umorstva. U tom kontekstu posebno činjenica da Jakšu nakon fizičkog ataka na Alibegu nitko nije proganjao bitno preusmjerava sugeriranu značenjsku liniju zaodjevajući je u novo ruho tajanstvenosti. Nameće se pitanje zašto prestavnici moći, upućenijem čitatelju poznati iz drugih djela kao „svirepi“ i „otrovni“25 ne kažnjavaju one koji ih evidentno atakiraju, a obračunavaju se s onima koji ni u čemu ne narušavaju njihovu prevlast (s Anikom s kojom je Alibega u nekoj vrsti ljubavne veze i koja nakon Jakšina napada na njega šalje svoju Ciganku da pita kako je, 72-73).

Kao što je već istaknuto, Andrićev princip tajnovitosti ${ }^{26}$ osebujna je narativna tehnika koja se ne uklapa niti u jedan od Genetteovih tipova fokalizacije. Kako zagonetnost Andrićeva teksta nije utemeljena niti na u naratologiji često spominjanom paradoksnom principu „otvorene tajne“ teško je uklopiti i u druge teorijske modele. Andrićeva naracija nije organizirana tako da su pripovijedni fakti čitatelju zatomljeni, a liku otkriveni. ${ }^{27}$ Ona nije ni tako postavljena da se „tajna uvijek zna“ kojom se kao svojevrsna „kamuflaža“ likovi „služe da bi jedni druge obmanuli“ potičući tako čitateljsko prozrijevanje. ${ }^{28}$ Andrićeva naracija nije postavljena ni tako da simulira ,otvorene tajne“ koje slijede „ritmove tajnovitosti“", sistoliju i distoliju, usrdno moleći da ih se ,pažljivo otkrije, a ne da ih se jednostavno i bez truda oda“. ${ }^{29}$ Informacije koje se daju u Andrićevu tekstu redovito razotkrivaju tek jedan aspekt prestavljenog, nerjetko puno više skrivajući nego pokazujući. One i nisu tu da bi bile otkrivene ili sakrivene nego da bi semantički nijansirale i ukazivale da je ispod verbalne površine diskursa još puno tajni koje se ne mogu izreći, nego tek naslutiti. Konačno, postavlja se pitanje značenja Andrićeve tajnovitosti onkraj navedene narativne tehnike. U okviru ovdje postavljene tematike pokušat ćemo odgonetnuti koliko je ona

25 Gligorić, V. Romani Ive Andrića, u: Kritičari o Ivi Andriću, ur. Milanović, B. (1977), Sarajevo, str. 182.

26 Tajnovitost i šutnja kao tehnike Andrićeve naracije u dosadašnjoj literaturi uglavnom su, na tragu čitanja I. Sekulić (1923) bile tumačene kao tipično istočnjački element; Gligorić, V. Romani Ive Andrića, u: Kritičari o Ivi Andri$c ́ u$, ur. Milanović, B. (1977), Sarajevo, str. 181-199; Peleš G. Tematski sustav Andrićevih kronika, u: Zbornik radova o Ivi Andriću, ur. Isaković, A. (1979), str. 499-514.

27 Bal, M. (1985) Narratology. Introduction to the Theory of Narrative, translated by Boheemen, C. V. Toronto, Buffalo, London, str. 115.

28 Miller, D. Tajni subjekti, otvorene tajne, u: Politika i etika pripovijedanja, ur. Biti, V. (2002) Zagreb, str. 91.

29 Newton, A. Z. Kazivanje drugih: Tajnovitost i spoznaja u Dickensa, ur. Biti, V. (2002) Zagreb, str. 107- 108. 


\section{BERNARDA KATUŠIĆ}

historijski uvjetovana, odnosno kako se „veliki“ Drugi odnosi prema njoj.

\section{Ars erotica i scientia sexualis}

Izokrenemo li na trenutak, isključivo u analitičke svrhe, Foulcautovo dijakrono promišljanje žudnje i ljudske seksualnosti, i pokušamo li teorijskim alatka njegova antipoda Lacana doprijeti do toga što bi za Foucaultu bila žudnja po sebi, onkraj svekolikog povijesnog konteksta, možemo istaći Tajnu ${ }^{30}$ kao njenu bit. Pomno čitanje Foucalutove teorijske građevine otkriva da se poznato autorovo razlikovanje povijesnih koncepata žudnje i ljudske seksualnosti temelji upravo na našem odnosu prema Tajni. S obzirom na to tražimo li je u sebi ili je posjedujemo i dajemo drugima, govorimo li o njoj ili je prešućujemo, te kako o njoj govorimo ili šutimo francuski teoretičar razlikuje ars eroticu, žudnju koja karakterizira Kinu, Japan, Indiju, Rim, arapsko-muslimanska društva i scientia sexualis, žudnju svojstvenu jedino našoj civilizaciji. Dok je u društvima koja prakticiraju ars eroticu žudnja poimana prema sebi samoj i intenzitetu u kojem se doživljava te kao takva shvaćana kao tajanstveno dobro koje se posjeduje i u određenom trenutku (aktu inicijacije) prenosi s majstora na učitelja, u društvima koja prakticiraju scientia sexualis žudnja je shvaćena kao „uznemirujuća zagonetka“"31 naše pojedinačnosti. Kao takva ona se ne posjeduje i ne prenosi nego se govorom, „,beskrajanim žrvanjem riječi“ (22) otkriva i stvara. Stoga je, kako zaključuje Foucault, čovjek na Zapadu ,postao priznavajuća životinja“, koja ili priznaje ili je prisiljena priznati (54). U tom kontekstu, šutnja Istoka je ,granica govora“, vrijeme koje još nije zrelo da se Tajna prenese, a šutnja Zapada jedan od elementa koji funkcionira pored onih izrečenih, s njima i u odnosu na njih u skupnim strategijama. Shodno tomu u modernim društvima ne postoji ,jedna nego više šutnji“ i sve su one ,sastavni dio strategija koje podržavaju i prožimaju govore“ (27).

Promotrimo li dijalošku scenu između Anike i Mihaila iz perspektive Foucaultova poimanja žudnje sve prethodno sugerirane semantičke i simboličke razine još se jednom revidiraju. Već je na prvi pogled vidljivo da je za Andrićev poetski svijet podjednako svojstvena i ars erotica i scientia sexualis, da se u njemu navedene ljubavne koncepcije međusobno ne isključuju i potiru,

30 Navedenu tezu implicira i činjenica da je Tajna nerijekto u Foucalutovim tekstovima istaknuta pisanjem velikim početnim slovom i u kurzivnom obliku; usp. Foucault, M. (2013) Volja za znanjem. Povijest seksualnosti, prev. Wurzberg, Z. Zagreb, str. 33).

31 Usporediti: Foucault, M. (2013) Volja za znanjem. Povijest seksualnosti, prev. Wurzberg, Z. Zagreb, str. 33. 
nego rasvjetljavaju i dopunjuju. Andrićevi likovi očito i šute i govore o žudnji i u duhu ars erotica i u duhu scientia sexualis. Kao što proizlazi iz dosadašnje analize pouzdano detektiranje njihovih (non)verbalnih aktivnosti nadilazi mogućnosti interpretativnih okvira. Njihovu šutnju moguće je iščitati i kao tajanstvenost „znanja kojeg posjeduju“, ali i kao jendu od strategija koja ,podražava i prožima govore“". S druge strane, njihov govor moguće je tumačiti kao nastojanje ,preobraziti onoga koga zapadnu njegovi darovi“ (53) ili kao „priznanje“ koje oslobađa. Suprostavljanjem navedenih dviju koncepcija žudnje i njihovim međusobnim značenjskim nijansiranjima, evidentno, Andrić ne diferencira i problematizira samo dva oprečna svjetonazora i stila življenja, nego više i prije pokušava prodirjeti do žudnje /tajanstvenosti kao takve koje se nikad do kraja ne mogu niti posjedovati niti otkiriti. Svi smo osuđeni za tek za njima tragati.

Sugerirani zaključak moguće je potkrijepiti promotrimo li navedenu problematiku u kontekstu cjelokupna Andrićeva djela. Grubo govoreći, ljubavne odnose prestavljene u autorovu djelu s obzirom na historijsko-politički kontekst moguće je podijeliti u tri skupine: ljubavni odnosi prestavljeni u turskim vremenima (primjerice, ljubavni odnos između Fate i Naila, Mare Milosnice i Veludin-paše ); ljubavni odnosi prikazani u vremenu austrijske okupacije (primjerice, ljubavni odnosi između Feduna i Jelenke, Ane Marije i von Mitterera, te Davida i njegove supruge) te suvremeni ljubavni odnosi (primjerice, ljubav između pripovjedača u prvom licu i Jelene, „žene koje nema“ ili između neimenovanog prijatelja naratora $i$,žene od slonove kosti“ $u$ istoimenoj pripovijesti itd.). Već površna usporedba navedenih ljubavnih diskurza upućuje na dvoje. Prvo, niti u jednom od prestavljenih odnosa ljubavna žudnja za ljubećim Drugim nije u potpunosti utažena, niti u jednom od ljubavnih odnosa niti ljubeći, niti ljubeća ne uspjeva dosegnuti žuđeni objekt. Drugo, razlozi zašto njihova žudnja nije utažena nisu identični. Njihova različitost uvjetovana je, između ostalog, kako povijesnim kontekstom tako i političko-socijalnom situacijom, odnosno međusobnim suprotstavljanima i osvjetljavanjima različitih dijakronih koncepcija žudnje. Detaljna analiza navedenih političkih razina, dakako, prelazi tematske okvire ovog članka.

\section{LITERATURA:}

Andrić, I. (1984) Jelena žena koje nema, Sabrana djela, Sarajevo.

Bal, M. (1985) Narratology. Introduction to the Theory of Narrative, translated by Boheemen, C. V. Toronto, Buffalo, London.

Bečanović, T. Kompozicioni principi Andrićevih pripovjedaka Anikina vremena i Mara, Milosnica, u: Ivo Andrić - književnik i diplomata 


\section{BERNARDA KATUŠIĆ}

u sjeni dvaju svjetskih ratova (1925-1941), ur. Tošović, B. (2012), Beograd, str. 91-117.

Brlenić-Vujić, B. Razlomljeni identiteti u Andrićevim pripovjetkama, u: Ivo Andrić - književnik i diplomata u sjeni dvaju svjetskih ratova (1925-1941), ur. Tošović, B. (2012), Beograd, str. 117-125.

Đuvić, M. (2016) Žena koje nema i njeno tijelo. (Re)konstrukcija ženskog subjekta u Andrića, http://www.razlika-differance.com/Razlika\%205/RD5-Djuvic.pdf, 20. 05. 2016.

Elliott, A. (2015) Psychoanalytic Theory: An introduction, London: Palgrave.

Fink, B. (2009) Lakanovski subjekt. Između jezika i jouissance, Zagreb.

Foucault, M. (2013) Volja za znanjem. Povijest seksualnosti, prev. Wurzberg, Z., Zagreb.

Freud, S. Zur Psychopathologie des Alltagslebens, u: Sabrana djela $I V$, ur. Freud, A., Bibring, E., Hoffer, W., Kris, E. i Isakower, O. (1940), London / Frankfurt.

Gazetić, E. (2016) Ne/predstavljivost ženskog subjekta u Andrićevim pripovijestima Anikina vremena, Mara milosnica i Jelena, žena koje nema, https:/www.ceeol.com/search/article-detail?id=33077, 20. 05. 2016.

Genette, G. (2010) Die Erzählung, Stuttgart.

Gligorić, V. Romani Ive Andrića, u: Kritičari o Ivi Andriću, ur. Milanović, B. (1977), Sarajevo, str. 181-199.

Hawkesworth, C. (1984) Ivo Andrić: Bridge between East and West, London.

Korać, S. Žena u Andrićevim pripovijetkama, u: Zbornik radova o Ivi Andriću, ur. Isaković, A. (1979), Beograd, str. 549-582.

Korać, S. (1989) Andrićevi romani ili svijet bez boga, Zagreb.

Lacan, J. (1973) Schriften I, ur. Haas, N., Walter Verlag: Olten / Freiburg.

Lacan, J. (1975) Schriften II, ur. Haas, N., Walter Verlag: Olten / Freiburg.

Lacan, J. (1978) Die vier Grundbegriffe der Psychoanalyse, Das Seminar von J. Lacan, ur. Miller, J. A. knjiga br. XI, Olten / Freiburg.

Lacan, J. (1988) The Seminar, Book II. The Ego in Freud's Theory and in the Technique of Psychoanalysis, 1954-55, New York: Nortion; Cambridge.

Lacan, J. (1993) The Seminar, Book III. The Psychoses, 1955-56, London. 


\section{BERNARDA KATUŠIĆ}

Lukić Visković, J. Dvije Andrićeve ženske priče: „Anikina vremena“ i „Mara milosnica“, u: Ivo Andrić - svugdašnji, ur. Brnčić, J. (2015), Zagreb, str. 101-125.

Miller, D. Tajni subjekti, otvorene tajne, u: Politika i etika pripovijedanja, ur. Biti, V. (2002), Zagreb, str. 81-103.

Minde, R. (1962) Ivo Andrić, Studien über seine Erzählkunst, München.

Newton, A. Z. Kazivanje drugih: Tajnovitost i spoznaja u Dickensa, u: Politika i etika pripovijedanja, ur. Biti, V. (2002), Zagreb, str. 103-129.

Peleš, G. Tematski sustav Andrićevih kronika, u: Zbornik radova o Ivi Andriću, ur. Isaković, A. (1979), Beograd, str. 499-514.

Ređep, D. (1981) IvoAndrić: Između Istoka i Zapada (varijacija na temu: treći svet), u: Delo Ive Andrića u kontekstu evropske književnosti $i$ kulture, Beograd, str. 517-525.

Sekulić, I. Istok u pripovetkama Iva Andrića, u: Kritičari o Ivi Andriću, ur. Milanović, B. (1977), Sarajevo, str. 50-59.

Stojanović, D. (2016) Lepota i mržnja, http://www.rastko.org.rs/knjizevnost/nauka_knjiz/andric/dstojanovic-anika.html, 20. 05. 2016.

Škvorc, B. Okcident i Orijent: Osmanlije i islam prema kršćanstvu. Ili: Andrićevi franjevci u pričanju (kolonijalne) priče, u: Ivo Andrić - književnik i diplomata u sjeni dvaju svjetskih ratova (1925-1941), ur. Tošović, B. (2012), Graz, str. 311-341.

Wermuth-Atikson, J. (2005) Between Orient and Occident: Damned Yard in the Context of European Aesthetics, Serbian Studies, No. 2, pp. 295-330. 


\title{
BERNARDA KATUŠIĆ
}

\author{
Bernarda Katušić \\ University in Vienna, Institute for Slavistics, Vienna, Austria
}

\section{ANIKA AND THE BIG OTHER}

\begin{abstract}
According to Lacan (1996), "the big Other" (le grand Autre) is a world of language where the self is constituted. It is often a space of empty signifiers in which the subject, deprived of any solid reference and radically decentred with endless slips of the "symbolic order", is caught in the narcissistic reflections of the mirror, dispersed and totally overcome by the very force of desire. Lacan believes that desire can be satisfied only with active engagement with "the big Other", in a "successful" interpersonal communication which is only possible in rare flash-like moments. This communicative situation is, hence, conceived as a location where desire can be satisfied, but also as a process of division, a necessary excuse which covers up an endless search for the missing object. Accordingly, based on Lacan's theoretical postulates, the paper analyses the functioning of the discourse of love, and the strategies of constituting the intimate self in the imperial social orders. By interpreting "full" and "empty" speech in Andrić's novella Anika's Times (1931), the paper attempts to show the ways in which the self, torn between desire for and deficiency of the Ottoman "big Other", is realised.
\end{abstract}

Key words: Andrić, Anika's Times, Lacan, big Other, Foucault, ars erotica 